$\frac{\text { AUNC }}{\text { Zabytkoznawstwo i Konserwatorstwo XLVIII }}$
Toruń2017
DOI: http://dx.doi.org/10.12775/AUNC_ZiK.2017.007

\title{
Painting works by Anton Möller on the background of Gdańsk's painting workshop of the last quarter of the 16th and the first half of the 17th century
}

\author{
BOŻENA SZMELTER-FAUSEK \\ Department of Painting Technology and Techniques, \\ Faculty of Fine Arts, Nicolaus Copernicus University in Toruń \\ e-mail: bozenasz@umk.pl \\ JUSTYNA OLSZEWSKA-ŚWIETLIK \\ Department of Painting Technology and Techniques, \\ Faculty of Fine Arts, Nicolaus Copernicus University in Torun \\ e-mail: justolsz@umk.pl
}

Keywords: Anton Möller, Gdańsk, easel painting, painting of 16/17th century

Słowa kluczowe: Anton Möller, Gdańsk, malarstwo sztalugowe, malarstwo XVI/XVII w.

\begin{abstract}
This works presents the research on painting technology and techniques of selected panel paintings by Anton Möller (1563/5-1611) and the paintings attributed to his workshop and circle of his artistic influences such as Isaac van den Blocke (before 1589-after 1924) and Hermann Han (1580-1627/8). Gdańsk's painting of the turn of the 16th and 17th centuries was a combination of technology and techniques derived from local traditions influenced by northern trends: German and Dutch, as well as their assimilated Italian art. The results of performed analysis revealed that the works

\footnotetext{
This article was based on interdisciplinary research carried out as part of research projects of Ministry of Science and Higher Education No. N 10503731/3704 (cat. no. of paintings 1-4, 17), National Science Center NN105430940 (cat. no. 1-4, 17), MNiSzW No. NN 204370340 (cat. no. 5-10, 12, 14-16, 18-23).
} 
by Anton Möller had a great influence on the development of the painting workshop in Pomerania. The white ground and grey imprimatura and colorful ground characteristic for the Gdańsk artist were identified, among others, in the Gronau epitaph and works by Hermann Han and Isaac van den Blocke. Artists working in this area could be influenced by the painting school of Anton Möller, and they could draw technical achievements directly from the Netherlands.

The dominant pigments in Möller's painting palette are lead white, lead-tin yellow, red and yellow iron pigments of natural origin, cinnabar, minium, organic red pigment, smalt, natural azurite, iron umber, charcoal. Anton Möller and Isaac van den Blocke as the only Gdańsk artists used natural ultramarine in their paintings.

Anton Möller's work distinguishes the use of bright colors similar to Italian and Flemish paintings. The artist in some way experimented with color. He used various colors of mortar, imprimatura, and underpainting to achieve the desired effect, including a white imprimatura for illuminating the surface of the painting or a pink gound layer for painting the sky. The composition of the painting was underpainted with brown paint that gave a warm tint. When painting garments, especially red, he used strong contrasts of shimmer, where the vivid red was assembled with a plane painted red with the addition of a large amount of lead white. These treatments were supposed to give the impression of luminosity, which brings even closer the way of color compositions with Italian painting. Anton Möller applied the principles of technology and painting techniques typical of the turn of the 16th and 17th centuries in European art and belongs to a group of outstanding artists active in Gdańsk.

\footnotetext{
Abstrakt

Anton Möller na tle gdańskiego warsztatu malarskiego ostatniej ćwierci XVI i pierwszej połowy XVII w.

Praca przedstawia badania techniki i technologii wybranych obrazów sztalugowych Antona Möllera (1563/5-1611) i obrazów przypisanych do jego warsztatu i kręgu jego oddziaływania artystycznego, jak dzieła Isaaca van den Blocke (przed 1589-po 1924) i Hermanna Hana (1580-1627/8). Gdańskie malarstwo przełomu XVI i XVII w. było połączeniem technologii i techniki wywodzącej się z tradycji lokalnej pozostającej pod dużym wpływem trendów północnych: niemieckich i niderlandzkich, oraz asymilowanych przez nich osiągnięć włoskiej sztuki malarskiej.

Przeprowadzone badania gdańskiego malarstwa ostatniej ćwierci XVI i pierwszej połowy XVII w. wykazały, że twórczość Antona Möllera miała duży wpływ na kształtowanie się warsztatu malarskiego na terenie Pomorza. Białą zaprawę i szarą imprimaturę oraz barwne zaprawy charakterystyczne dla gdańskiego artysty zidentyfikowano między innymi w epitafium Gronau i obrazach Hermanna Hana oraz Isaaca van den Blocke. Artyści działający na tym terenie mogli być zarówno pod wpływem gdańskiej szkoły malarstwa, Antona Möllera, jak i mogli czerpać techniczne osiągnięcia bezpośrednio z Niderlandów.

Dominujące pigmenty w palecie malarskiej Möllera to biel ołowiowa, żółcień cynowo-ołowiowa, żółte i czerwone pigmenty żelazowe pochodzenia naturalnego,
} 
cynober, minia, czerwony pigment organiczny karmin, smalta, azuryt naturalny, umbra żelazowa, czerń roślinna. Anton Möller i Isaac van den Blocke jako jedyni artyści gdańscy zastosowali w swoich obrazach ultramarynę naturalną.

Twórczość Antona Möllera wyróżnia zastosowanie jasnej kolorystyki zbliżonej do malarstwa włoskiego i flamandzkiego. Artysta w pewien sposób eksperymentował z kolorem. Wykorzystywał różne kolory zaprawy, imprimatury i podmalowania do osiągnięcia zamierzonych efektów, między innymi białą imprimaturę do rozświetlenia powierzchni obrazu, czy różową zaprawę do namalowania nieba. Kompozycję obrazu podmalowywał brązową farbą, o ciepłym odcieniu, która nadawała ciepły koloryt. Malując szaty, szczególnie czerwone, stosował silne kontrasty światłocieniowe, gdzie żywą czerwień zestawiał z płaszczyzną namalowaną przy użyciu czerwieni z dodatkiem dużej ilości bieli ołowiowej. Zabiegi te miały wywołać wrażenie świetlistości, co jeszcze bardziej zbliża sposób kompozycji barwnych z malarstwem włoskim. Antona Möller stosował zasady technologii i techniki malarskiej typowej dla przełomu XVI i XVII w. w sztuce europejskiej i należy do grona wybitnych artystów działających w Gdańsku.

Anton Möller was born in 1563/1565 in Königsberg and he died in 1611 in Gdańsk. He is one of the leading artists of Pomerania region of the end of the 16th and the first half of the 17th century. He mainly painted works presenting biblical and allegorical scenes on the background of the buildings of Gdańsk. His paintings were primarily intended for exhibiting in public buildings as well as in churches. As a painter, he ran a painting workshop that was significant in Pomerania and which contributed to the formation of one of the most important artistic centres in Gdańsk. Other artists who also had a significant influence on the artistic formation of painting workshops in Pomerania were: a Dutch Hermann Han (1580-1626/1627), born in Gdańsk, who, apart from Gdańsk, also maintained a workshop in Chojnice, as well as two artists from the Netherlands: Hans Vredemann de Vries (1527-1604) - an architect, interior decorator and a painter and Isaac van den Blocke (before 1589-after 1624), a painter and a member of the Flemish family from Mechelen.

At the turn of the 16th and 17th centuries the Gdańsk painting was a combination of techniques derived from the local tradition, which were strongly influenced by northern trends in paintings: German and Dutch, and the assimilated achievements of Italian painting ${ }^{1}$.

Willi Drost, Danziger Malerei vom Mittelalter zum Ende des Barock. Ein Beitrag zur Begründung der Strukturforschung in der Kunstgeschichte (Berlin, Leipzig: Verlag für Kunstwissenschaft, 1938), 117-121; Jacek Tylicki, "Sztuka Prus Królewskich. Malarstwo i rysunek", in Prusy Królewskie. Społeczeństwo, kultura, gospodarka 1454-1772, ed. Edmund Kizik (Gdańsk: Muzeum Narodowe w Gdańsku, 2012), 309-370, fig. 1-35. 
Twenty three paintings were selected to determine the essential features of the Gdańsk painting workshop: five paintings by Anton Möller (cat. no. 5, $10,12,14,15)$, two assigned to his circle of artistic influence (cat. no. 11, 17), one by Isaac van den Blocke (cat. no. 13), seven by Hermann Han (cat. no. 16, 18-23), four paintings with allegorical scenes attributed to Han's workshop (cat. no. 6-9) and four paintings from epitaphs from the St. Mary's Church in Gdańsk (cat. no. 1-4). The selection of works was determined by the choice of representative works but also by their availability and the consent of individual institutions. The most significant works were chosen, allowing for a thorough and precise characterization of painting technology and techniques. The list of works and examination results are included in tables 1 . and 2. The order of works in the table was done according to the date of completion. Table 1. contains the types of materials used and the technique concerning such issues as the type of support, ground layer, drawing, isolation layer, imprimatura and underpainting layers. Table 2. contains the results of examination of pigments and gilding in the analysed paintings ${ }^{2}$.

2 The traditional and modern non-invasive and microinvasive methods, physical, chemical and instrumental analysis were used to study the technology and techniques of Gdańsk's paintings. Most of the preliminary tests, including sampling and analysis of the state of preservation in the light of the VIS, infrared IR and UV were carried out by the authors of the article, specialized tests: in colour infrared (false colour IR technique), XRF X-ray fluorescence spectroscopy - dr hab. Jarosław Rogóż, prof. NCU, Adam Cupa, Department of Painting Technology and Techniques of Nicolaus Copernicus University in Toruń; portable XRF research - dr Mirosław Sawczak, Institute of Fluid-flow Machinery Polish Academy of Sciences in Gdańsk; SEM-EDS analyses - prof. dr hab. eng. Maciej Pawlikowski, Department of Mineralogy, Petrography and Geochemistry of the University of Science and Technology in Kraków; M. Wróbel, Laboratory of Electron Microscopy and Microanalysis, Institute of Hydrogeology and Engineering Geology, Faculty of Geology, University of Warsaw; Grzegorz Trykowski, Grażyna Szczepańska, Faculty of Chemistry, Nicolaus Copernicus University in Toruń; x-ray examinations - Roman Stasiuk and Piotr Zambrzycki, Documents Laboratory, Department of Conservation and Restoration of Works of Art at the Academy of Fine Arts in Warsaw; stratigraphy studies of samples, layering, chronology and preliminary estimation of the composition of pigments, dyes and binders were made by means of comparative analysis using standard VIS microscopy and UV fluorescence microscopy - dr Zuzanna Rozłucka, Department of Conservation of Painting and Polychromed Sculpture NCU in Toruń; studies of crystalline pigments on cross-sections of samples using $\mu$-XRPD x-ray microdiffraction prof. dr hab. Wiesław Łasocha, dr Alicja Rafalska-Łasocha, Department of Crystal Chemistry and Crystalophysics, Faculty of Chemistry, Jagiellonian University in Kraków, and dr Marta Grzesiak-Nowak, Institute of Catalysis and Surface Chemistry, Polish Academy of Sciences in Kraków; Neutron Activation Analysis - mgr inż. Ewa Pańczyk, Institute of Nuclear Chemistry and Technology in Warsaw; testing of adhesives on powdered samples using the FTIR method - dr Adam Balewski, MA Wiesława Topolska, Department of Conservation of Elements and Architectural Details NCU in Torun; testing of adhesives by gas chromatography 
The end of the sixteenth century is associated with progressive changes in the technique of European painting, in which linen canvas and coloured emulsion ground layers were introduced.

Anton Möller painted mainly on wooden supports made of oak boards. His paintings are characterized by different formats and shapes, which depended on the function and purpose of the painted work. The smallest format is represented by the Portrait of the Bishop Mauritius Ferber (cat. no. 5) $(88.7-89 \times 56.5 \mathrm{~cm})$. The paintings of large format are: Seven Acts of Charity (cat. no. 12) (291 x $189 \mathrm{~cm})$ and Crucifixion (cat. no. 15) (304 x $233 \mathrm{~cm})$. The predella The Last Supper (cat. no. 14) coming from the altar of Crucifixion of the Lord, has a dimension of $62 \times 248 \mathrm{~cm}$. Other paintings at the top, ending with a semi-ellipse and a semi-circle are: the Tribute Money (cat. no. 10) and the Rebuilding of the Temple. In all the works, the planks of the support were joined together, and in the case of the Tribute Money and the Rebuilding of the Temple, the wooden reinforcements in the shape of the so-called double dovetail were placed on the joints ${ }^{3}$. The support of the Crucifixion was reinforced with two boards let in from the reverse on the so-called swallow's tail.

Epitaph paintings from St. Mary's Church in Gdańsk were executed on wooden supports made of oak. Isaac van den Blocke preferred support made of oak wood, which served him to paint the Servilius Appius (cat. no. 13) and other paintings displayed on the ceiling of the Red Hall of the Main City Hall of the City of Gdańsk.

Besides oak, Hermann Han used also linden-wood supports, which was not so popular in the Gdańsk workshops, where oak wood dominated, as in the case of northern masters,

The paintings in the collection of the National Museum of Gdańsk and Poznan titled Allegory of Pride, Allegory of Wealth and Model of the World (cat. no. 6-9) from around 1600 were painted on oak planks. Dendrochronolog-

- Grzegorz Jaworski, Department of Painting Technology and Techniques NCU in Torun; research using the micro-Raman spectroscopy method - dr hab. Edyta Proniewicz, prof. AGH (Akademii Górniczo-Hutniczej), dr Ewa Pięta, Laboratory of Laser Raman Spectroscopy, Faculty of Chemistry, Jagiellonian University in Kraków.

3 Due to the large format of the Tribute Money and the Rebuilding of the Temple and Seven Acts of Charity and the technical problems connected with this fact, it was not possible to analyse the supports from the reverse. In addition, the Rebuildnig of the Temple has a parquet support mounted from the reverse, which further hindered the analysis of the support. The measurements were made on the sufrace for these three paintings. The Portrait of the Bishop Mauritius Ferber, the Last Supper and Crucifixion was analyzed from the reverse. 
ical studies of two pantings Allegories of Pride, one of Gdańsk and the other of Poznań, showed that they were made of oak wood, so-called Baltic type $\mathrm{B} 1$ in the case of the painting from Gdańsk, and "NL" type in the case of the painting from Poznań. B1 wood is also found in the Georg Hojer's epitaph from 1585. Boards from these paintings originate from the areas located East of today's Polish borders ${ }^{4}$.

Wooden canvas paintings dominated in the Gdańsk painting from the fifteenth to the early seventeenth century ${ }^{5}$. Since about 1500 canvas supports had spread first in Italy, and then among artists of Northern Europe, such as Albrecht Dürer (1471-1528) . Anton Möller was also influenced by new trends in the use of linen canvas in European modern painting. The only known painting by Möller made on canvas support has not preserved, the Last Judgment (1602-1603) from the Artus Court in Gdańsk. The painting had the shape of a standing rectangle $(780 \times 600 \mathrm{~cm})$ closed at the top with ogive. In the works of Hermann Han, similarly to Möller's, apart from paintings made on wooden supports, there is one known painting on canvas - Coronation of Mary (1623) from the cathedral in Pelplin, of the shape of a standing rectangle and dimensions $507 \times 303 \mathrm{~cm}$. These two paintings are of the largest format in the oeuvre of each artist ${ }^{7}$.

Canvas supports were used by Möller in 1602 and by Han in 1623 and it shows that Gdańsk artists had turned to new trends in the use of this type of painting supports. At the end of the 16th century, one of the few artists in Gdańsk who painted on canvas was Hans Vredemann de Vries, who came

4 Dendrochronological research was made by prof. dr hab. Tomasz Ważny. See Kristof Haneca et al., "Provenancing Baltic Timber from Art Historical Objects: Success and Limitations", Journal of Archeological Science, nr 2/32 (2005), pp. 261-271.

5 Maria Roznerska, Techniki malarskie "małych mistrzów holenderskich” XVII w. (Toruń: Uniwersytet Mikołaja Kopernika, 1991), 149; Max Doerner, Materiały malarskie i ich zastosowanie (Warszawa: Arkady, 1975), 304; Bohuslav Slánský, Technika malarstwa, vol. 2 (Warszawa: Arkady, 1965), 263.

6 Bogumiła J. Rouba, „Płótna jako podobrazia malarskie”, Ochrona Zabytków 3-4 (1985): 223.

7 In Möller's and Han's oeuvre there is only one known painting on canvas support besides paintings on wodden ones. The Last Judgement by A. Möller was lost in the II World War, Teresa Labuda, „Sąd Ostateczny” Antoniego Möllera z Dworu Artusa w Gdańsku: problemy ikonografii, Gdańskie Studia Muzealne, Tom 4 (1985), s. 220-221, 69-78, reference 1; and the painting Coronation of Mary by H. Han, Barbara Szolginia and Teofil Dąbrowski, Konserwacja obrazu H. Hana „Koronacja NMP” z Głównego Ołtarza Katedry w Pelplinie, dokumentacja prac konserwatorskich, Gdańsk 1957, Wojewódzki Urząd Ochrony Zabytków, sygn. ZR/113/1, mps.; compare Bożena Szmelter-Fausek, "Wybrane obrazy ołtarzowe Hermanna Hana (1580-c. 1628) - zagadnienia technologiczne i konserwatorskie”, in Історія релігій в Україні, vol. 2 (Леви: Львівський музей історії релігії 2012), pp. 609-616. 
from the Netherlands. In 1594, he made paintings on linen canvas for the Artus Court, and in 1595 to the Red Hall of the Main Town Hall of the City of Gdańsk $^{8}$. Two other examples of paintings on canvas from the end of the 16th century are displayed in the parish church in Puck. These are two Portraits of Maria Mortęski and Ernest Wejher, dated on 1597, and attributed to Herman Han'. The paintings from the Christian Henning's family epitaph (Christian Henning died in 1626) from the National Museum in Gdańsk, attributed to Han, were the only paintings made on a copper sheet ${ }^{10}$.

In the sixteenth and seventeenth centuries supports and grounds were prepared in accordance with the fifteenth-century tradition, about which Cennino Cennini was writing ${ }^{11}$.

Before the ground was applied, the surface of the support was glued with glutine glue. Anton Möller, depending on the period of his work, used white and coloured grounds. In the initial period around 1600, white chalk and glue ground and white imprimatura dominated. In later works, ca. 1609, two-coloured or white grounds with a local, mostly brown underlayer can be identified. In white grounds, the filler is chalk (natural calcite $\mathrm{CaCO}_{3}$ ), and the binder is a glutine glue. The ground is applied in approx. 2-3 layers with a thickness from ca. $77 \mu \mathrm{m}$ (cat. no. 10) to $160 \mu \mathrm{m}$ (cat. no. 12) ${ }^{12}$. Lead white is the filler of white oil imprimatura with a thickness of 7-14 $\mu \mathrm{m}$ (cat. no. 10), in the composition of which hydrocerusite was identified (Fig. 1). Brown oilbased underlayer with a thickness of 14-35 $\mu \mathrm{m}$, composed of: iron yellow, red and brown pigments, lead white (hydrocerusite and cerusite) and finely ground organic black (cat. no. 12).

\footnotetext{
Anna Gosieniecka, Wzory graficzne w malarstwie pomorskim drugiej połowy XVI i początków XVII wieku („Ze studiów nad sztuką XVI w. na Śląsku i w krajach sąsiednich”, ed. Bożena Steinborn) (Wrocław: Muzeum Śląskie, 1968), 111-132; Juliusz A. Chrościcki, ,’’Orfeusz i Eurydyka' Hansa Vredemana de Vries na tle tradycji ikonograficznej, in Dwór Artusa w Gdańsku. Sztuka i sztuka konserwacji, Dwór Artusa 17-19 października 2002, ed. Teresa Grzybkowska and Joanna Talbierska (Gdańsk: Oficyna Pomorska, 2004), 123-141.

9 Janusz Pasierb, Malarz gdański Herman Han (Warszawa: Wydawnictwo Naukowe PWN, 1974), 14-15; Katalog zabytków sztuki w Polsce, t. 5 Województwo gdańskie, z. 2 Puck, Żarnowiec i okolice, red. Barbara Rol and Iwona Strzelecka (Warszawa: Wydawnictwo Artystyczne i Filmowe, 1989), 40; Gosieniecka, Wzory graficzne, 61-62.

10 Gosieniecka, Wzory graficzne, 68-69.

11 Cennino Cennini, Rzecz o malarstwie. Teksty źródłowe do dziejów teorii sztuki, vol. 3, ed. Juliusz Starzyński (Wrocław: Ossolineum, 1955), chapter 113.

12 The thickness of the ground layer was measured only in these two paintings.
} 
In four epitaphs from St. Mary's Church in Gdańsk (cat. no. 1-4), a white chalk-glue ground was used, and in the Michael Loitz's epitaph (Fig. 2), similarly as in Möller's the Tribute Money, a lead white imprimatura was also applied on white chalk-glue ground. The imposition of a white layer of lead white oil imprimatura was characteristic of the 15th-century Flemish paintings by Dirck Bouts (1415-1475) and by Hans Memling $(1435-1494)^{13}$, also in the sixteenth century including Jan van Scorel (1495-1562) and Maarten van Heemskerck (1498-1574) $)^{14}$. This layer was an insulation as it reduced the absorptivity of the ground, at the same time allowing a stronger reflection of light passing through higher layers ${ }^{15}$.

A characteristic feature of Anton Möller's late work was the use of two-coloured grounds: the first yellow and the second pink (cat. no. 15). The pink layer also played the role of an underpainting and was used in some parts of the sky to develop the colour and chiaroscuro. Probably these are the influences of Italian painting, the achievements of which inspired many artists of that time. The Haarlem mannerist painter Jan van Scorel was inspired by the Italian painting. In the painting of the Lamentation of Utrecht he underpainted the blue robe with pink colour. He also used the pink colour of the ground to paint the sky in the Baptism of Christ from Haarlem ${ }^{16}$.

From the sixteenth century the coloured ground and imprimatura became popular in the painting of Pomerania, including Gdańsk. The Last Judgment located in the church of Saint James in Torun and assigned to Anton Möller's circle (dated on 1603) was painted on a three-coloured ground layer. The first layer of the ground is yellow, the second is grey and the third is dark grey. The yellow ground was obtained by mixing iron yellow, chalk, small addition of minium, lead white and charcoal. The grey layer was obtained from lead white and charcoal, and the dark grey by adding more black to the

13 Molly Faries, Christa Steinbüchel and Johan R. J. van Asperen de Boer, "Maarten van Heemskerck and Jan van Scorel's Haarlem Workshop”, in Historical Painting Techniques, Materials, and Studio Practice, Preprints of a Symposium, University of Leiden, the Netherlands, 26-29 June 1995, ed. Arie Wallert, Erma Hermens, and Marja Peek (Marina Del Rey, Calif.: Getty Conservation Institute, 1995), 136-137; Józef Flik and Justyna Olszewska-Świetlik, Tryptyk „Sąd Ostateczny” Hansa Memlinga z Muzeum Narodowego w Gdańsku. Technologia i technika malarska (Toruń: Wydawnictwo Naukowe UMK, 2005), 34.

14 Faries, Steinbüchel and van Asperen de Boer, “Maarten van Heemskerck”, 136-137.

15 Flik and Olszewska-Świetlik, Tryptyk, 34.

16 Jan P. Filedt Kok, Willy Halsema-Kubes and Wouter Th. Kloek, Kunst voor de beeldenstorm: Noordnederlandse kunst 1525-1580: Catalogus (Amsterdam: Rijksmuseum, 1986), 106-116, here: 109 . 
mixture. Grey layers were also used as an underpainting and to develop dark clouds. Emulsion binder was used in all three layers ${ }^{17}$.

Isaac van den Blocke used a white chalk-glue ground and a grey oil imprimatura from lead white and charcoal in the painting Servillius Appius ${ }^{18}$ (cat. no. 13; Fig. 3).

Two-coloured ground layers were also used in the painting from the Hans Gronau's family epitaph (cat. no. 17) from 1612 and assigned to the circle of Anton Möller. The first ground layer is of white chalk-glue, whereas the top layer is brown, in which minium, chalk, charcoal and fat emulsion binder were used (Fig. 5) ${ }^{19}$.

Hermann Han, belonging to a generation of younger painters than Möller, used grey grounds consisting of lead white, charcoal (of wood) and sometimes with a small addition of chalk (cat. no. 16, 18-21; Fig. 4). The exception is St. Elisabeth serving the sick man (cat. no. 23), where there are two layers of ground: white chalk and grey with an admixture of charcoal.

Allegorical and moralizing paintings from the museum in Gdańsk and Poznań of an unknown provenance and assigned to the Hermann Han's circle (cat. no. 6-9) were painted on a very thin white chalk and glue ground of a thickness of approx. 10-50 $\mu \mathrm{m}$. Natural calcite $\mathrm{CaCO}_{3}$ was used as chalk, and in the Model of the world - calcite with an addition of quartz $\mathrm{SiO}_{2}$ (Fig. 5). The ground layer is thin and only fills the pores of the wood, which indicates that it was applied using a putty knife or knife. This method is in accordance with de Mayerne's guidelines for the way of applying perfectly smooth ground layer ${ }^{20}$. Very thin grounds are typical for Dutch paintings of the 15 th

17 Bożena Szmelter-Fausek and Justyna Olszewska-Świetlik, “The Study on Technology and Technique of the Painting 'Last Judgement' from St. James Church in Toruń", in Interdisciplinary Research on the Works of Art, ed. Justyna Olszewska-Świetlik, Joanna A. Arszyńska, and Bożena Szmelter-Fausek (Toruń: Wydawnictwo Naukowe UMK, 2012), 209-217, here: 212 .

18 Ewa Pięta et al., "Micro-Raman Spectroscopy Analysis of $17^{\text {th }}$ Century Panel Painting 'Servilius Appius' by Isaac van den Blocke”, Journal of Raman Spectroscopy 45/11 (2014): 1019-1025.

19 Justyna Olszewska-Świetlik, Technologia i technika malarska wybranych nowożytnych epitafiów z Bazyliki Mariackiej w Gdańsku (Toruń: Wydawnictwo Naukowe UMK, 2009), 87, 109-110.

20 Theodore Turque de Mayerne, "Pictoria, Sculptoria, Tinctoria at quae subalternarum atrium, [...]", 1620, in Ernst Berger, Quellen für Maltechnik während der Renaissance und deren Folgezeit (XVI-XVIII Jahrhundert) in Italien, Spanien, den Niderlanden, Deutschland, Frankreich und England nebst den de Mayerne Manuscript, 3 Teil (München: Callwey, 1901), 276, in: Roznerska, Techniki malarskie, 163. 
and 16th centuries, in which the thickness ranged from 12 to approx. $40 \mu \mathrm{m}^{21}$. A very thin brown oil or oil-resin imprimatura was placed on the surface of the ground layer, which is about $7 \mu \mathrm{m}$ thick, consisting of iron brown pigment and organic black. In the paintings depicting the Allegory of Pride and Wealth and the Model of the World, the imprimatura was supposed to reduce the absorption of the ground.

After applying the ground on the canvas, the artists began to plan the composition of the painting. Anton Möller certainly used preparatory sketches. He is known for his drawing project made in 1595 to the painting of the Last Judgment to the Artus Court ${ }^{22}$. The design of the composition was transferred to the canvas, probably with the help of patterns, using the method of charcoal, then the drawing was reinforced by brush with black water paint.

Drawing made with water paint by brush appears in three epitaphs (cat. no. 1-3) dated to the second half of the 16th century and in Möller's Portrait of the Bishop Mauritius Ferber (cat. no. 5; Fig. 6). The author's drawing corrections can be seen in the composition of the so-called pentimenti. The same was observed in paintings of the Servilius Appius by Isaac van den Blocke (cat. no. 13) and the Assumption of Mary by Hermann Han (cat. no. 21). Gdańsk painters searched for the right shape, form and proportion, which proves their creativity and puts them among the creative artists who produced high-quality painting works.

From the fifteenth century drawing patterns have often been used in European painting workshops to prepare the composition ${ }^{23}$. At the beginning of the 17th century, engravings by Lucas Cranach the Elder (1472-1553), Jakub de Gheyn II (1565-1629), Aegidius Sadeler (1570-1629) according to Christoph Schwarz (1545-1592), or Zacharia Dolendo (1561-?) according to Karl van Mander, were popular in Poland ${ }^{24}$. These engravings were repeatedly re-

21 Filedt Kok, Halsema-Kubes and Kloek, Kunst voor, 107-108.

22 Janusz S. Kębłowski, ,'Sąd Ostateczny’ Antoniego Möllera na tle tradycji tematu w XV i XVI wieku”, in Dwór Artusa w Gdańsku, 143.

${ }_{23}$ Jacek Tylicki, Rysunek gdański ostatniej ćwierci XVI and pierwszej połowy XVII wieku (Toruń: Wydawnictwo UMK, 2005), 14; Johannes Voss, „Rysunki warsztatowe późnośredniowiecznych rzeźbiarzy”, in Od badań do konserwacji. Materiały z konferencji 23-24 października 1998 r. (Toruń: Wydawnictwo Naukowe UMK, 2002), 123-131; Józef Flik et al., „Rysunek w malarstwie sztalugowym - badania reflektografii w podczerwieni”, in Księga pamiątkowa ofiarowana profesorowi Wiesławowi Domasłowskiemu, ed. Bożena Soldenhoff (Toruń: Wydawnictwo Naukowe UMK, 2002), 47-81.

24 Mieczysław Morka, „Crucifixion Christopha Schwarza - polskie warianty”, Rocznik Historii Sztuki 20 (1994): 87-108. 
produced by Pomeranian painting workshops, as evidenced by the occurrence of paintings with similar, almost identical compositions, like the engraving by Jan Sadeler according to Christoph Schwarz from around 1590 with the presentation of the vision of the Last Judgment. This engraving was copied by the artist at the turn of the 16th and 17th centuries - especially in Pomerania. The most faithful repetition of this composition is the painting from the parish church in Świecie (1590?) and the picture from the parish church in Łęgów (Warmińsko-Mazurskie Voivodeship). The influence of the engraving is also noticeable in the Gronau's epitaph (1612) from the St. Mary's Church in Gdańsk (cat. no. 17) ${ }^{25}$.

The palette of Anton Möller's painting consisted of characteristic pigments of the turn of the 16th and 17th centuries, as: lead white $2 \mathrm{PbCO}_{3} \mathrm{x}$ $\mathrm{Pb}(\mathrm{OH})_{2}$, lead tin yellow type I and $2 \mathrm{PbOxSnO}_{2}$, organic yellow pigment, iron yellow and red of natural origin, minium $\mathrm{Pb}_{3} \mathrm{O}_{4}$, vermilion $\mathrm{HgS}$, organic red pigment with an indication for carmine (coshenilla), natural azurite $2 \mathrm{CuCO}_{3}$ $\mathrm{x} \mathrm{Cu}(\mathrm{OH})_{2}$, smalt $\mathrm{CoO} \times \mathrm{nK}_{2} \mathrm{SiO}_{3}$, natural ultramarine $3 \mathrm{Na}_{2} \mathrm{O} \times 3 \mathrm{Al}_{2} \mathrm{O}_{3} \times 6 \mathrm{SiO}_{2}$ x $2 \mathrm{Na}_{2} \mathrm{~S}$, copper green with an indication for malachite $2 \mathrm{CuCO}_{3} \times \mathrm{Cu}(\mathrm{OH})_{2}$, umber of natural origin, charcoal black.

Comparing the painting palette used in epitaph paintings from the St. Mary's Church in Gdańsk and the work by Isaac van den Blocke, a similar trend in the selection of pigments can be noticed. In all works except the Johann Connert's epitaph (cat. no. 1) lead-tin yellow type I and minimum are present. The other pigments found in the paintings are iron yellow and red, vermilion, organic red - carmine, and in the painting from the Gronau's epitaph (cat. no. 17) also red lake, smalt and natural azurite. Natural ultramarine is also present in the painting of Servilius Appius (cat. no. 13). Natural malachite (cat. no. 1 and no. 2) and copper green (cat. no. 2 and 4) were used as green pigments. The painting palette by Hermann Han and three paintings from the cycle Model of the World (MNP) and Allegory of Pride (MNG) is similar to the palette of other analysed paintings. There is not only natural ultramarine and malachite characteristic of 15 th and 16th century paint-

25 The painting was made after 1601, when the parish was founded in Łęgów. Until 1957 it was placed in the main altar, later on it was probably stored in the parish, "O obrazach w ołtarzu głównym w kościele w czasach powojennych”, Oficjalna Strona Łęgowa 10 (2007), http://www.legowo.schoolpage.pl/2007-4.html, Access 5 June 2017; Gosieniecka, Wzory graficzne, 128; Bernhard Schmid, Die Bau- und Kunstdenkmäler des Kreises Marienburg, Heft II (Danzig: Verlag des Provinzial-Verbandes von Westpreuszen. Kommissionsverlag von A. W. Kafemann G. M. B. H., 1919), 51-53, Fig. 8, 9. 
ing - instead there is a copper resinate (cat. no. 19, 21). Hermann Han also obtained green from a mixture of natural azurite and lead white, which he applied to yellow underlayer of lead tin yellow with the addition of iron red (cat. no. 22; Fig. 7). Charcoal black (of wood) is present in all Han's paintings.

Lead white was the pigment most commonly used in painting from antiquity to the mid-nineteenth century ${ }^{26}$. Studies on the composition of lead white in terms of trace impurities made for Gdańsk paintings showed that both Anton Möller and Hermann Han, as well as the authors of epitaph paintings from the St. Mary's Basilica in Gdańsk used lead white that was popular in the northern European countries ${ }^{27}$.

In the paintings by Anton Möller, the binder of the painting layer is oil and oil-resin with the composition of linseed oil with an addition of nut oil and natural resin. The paintings of the Gdańsk school were painted with emulsion-binder paint obtained by mixing linseed oil and protein (egg yolk or casein) and / or oil-resin: linseed oil and probably natural resin (cat. no. 1, 3, 4, 6-9, 11-12, 16-23).

The painting style in Möller's paintings and in paintings from the Gdańsk workshops is characterized by multilayeredness. The artists used underpainting layers and lake layers. Paints were usually applied in two to three layers, and in some parts of the paintings up to five.

In Gdańsk painting until the beginning of the 17th century, the painters started painting with an underlayer en grisaille of a mixture of white and black.

Anton Möller began painting a composition with iron brown. He put brown in the darkest parts of the composition. While developing some of the red robes, he initially made a chiaroscuro work with brown in shadows and white in the lights, then applied red lakes of organic red. In the development of red he also used vermilion and iron red (Fig. 8). Hermann Han modelled garments

\footnotetext{
Slánský, Technika, 49.

27 Olszewska-Świetlik, Technologia, 113-114; Bożena Szmelter-Fausek, “Gdański warsztat malarski ostatniej ćwierci XVI i pierwszej połowy XVII w. na przykładzie twórczości Antona Möllera (1563/5-1611) i Hermanna Hana (1580-1627/8)“ (PhD, Nicolaus Copernicus University, Torun 2013), 286, Annex, tabel 114. The compound of the lead white was estimated, Szmelter-Fausek, “Gdański warsztat', 288, Annex, tabel 115. In the painting Seven Acts of Charity two tyoes of whitewas identified: the first compose of the hydrocerusite and ceruzyt, the second of hydrocerusite. Hydrocerusite and cerusite was identified in the painting Assumption of Mary, and the white of hydrocerussite was identyfied in the painting of the Tribute Money and in Prussian attack on the monastery in Oliwa, Coronation of Mary, Allegory of Pride (National Museum in Gdańsk), Allegory of Pride (National Museum in Poznań).
} 
in a similar way. He painted vivid red with vermilion, especially in the parts of red robes and details of ornaments, as well as to underline roses on the cheeks.

Natural azurite and smalt were the dominant blue pigments in the paintings. Ultramarine was also identified in Seven Acts of Charity, in the Last Supper, in Crucifixion by Möller and in Servilius Appius by Isaac van den Blocke (Fig. 8). Smalt was a popular pigment often used. Anton Möller used cobalt glass to paint most of the blue garments and in a mixture with carmine to get purple shades ${ }^{28}$. Azurite was used in a limited amount to paint the details of clothing. Hermann Han used smalt mainly in the parts of the blue sky, where he mixed the pigment with lead white and less often to paint blue robes (Adoration of the shepherds, Assumption of Mary). He developed robes mainly with azurite, some with smalt. In the Allegory of Pride and in the paintings from the cycle Model of the World, smalt occurs mainly in the parts of the sky and occasionally in some blue robes.

The purples in Gdańsk painting were obtained by mixing red with blue: organic red - carmine or vermilion with smalt (cat. no. 3, 10; Fig. 3) or with natural azurite (cat. no. 7, 22). Sometimes vermilion was mixed with smalt (cat. no. 3). A dark shade was obtained by adding a little bit of charcoal to a mixture of azurite and organic red (cat. no. 1) and a cool shade of pink by adding lead white to smalt and carmine (cat. no. 2; Fig. 2).

Anton Möller developed the complexion of face and hand in a subtle way using a mixture of vermilion and lead white. He painted the highest lights with lead white. He applied red organic lakes on the cheeks and lips. He marked the shadows on chins with parallel, delicate lines of iron brown (Fig. 9). Isaac van den Blocke painted complexion by mixing lead white with minium and iron brown.

Aas one of the few Gdańsk artists Anton Möller signed his works, both paintings and drawings. All analysed paintings by Anton Möller, except for those created shortly before the artist's death - Crucifixion and the Last Supper (cat. no. 15 and 14) - are signed with the $A M$ in ligature next to the date on the surface of the work. The signatures were made very carefully with black-brown paint using a round pointed brush. The earliest painting signed by Möller is the Portrait of the Bishop Mauritius Ferber (cat. no. 5) -

28 Bożena Szmelter-Fausek and Justyna Olszewska-Świetlik, Blue Pigments in Blue and Purple Painting Layers of Gdan'sks' Paintings of the Mid-16th to the End of the 18th Century, "Colour research and application”, vol. 41, Issues 3, s. 270-275, June 2016, ISSN 1520-6378, ISSN: 0361-2317, DOI: 10.1002/col.22030. 
$A M \cdot 1590 \cdot$ The next can be found in the Tribute Money (cat. no. 10) - AM 1601, the Rebuilding of the Temple - AM 1602. and Seven Acts of Charity (cat. no. 12) - AM 1607. (Fig. 10).

In Gdańsk painting the artists also used gilding techniques, although to a limited extent to make radiant glories or inscriptions. White, yellow and red primer paints with an oil-resin bond and oil and resin mixtion were used. Anton Möller made gilding, among others in the non-existing Last Judgment of the Artus Court in Gdańsk, in the Tribute Money (cat. no. 10), in the Last Supper (cat. no. 14) and in the Crucifixion (cat. no. 15). The gilding was also made in the Gronau's epitaph from the St. Mary's Church in Gdańsk (cat. no. 17), in the Last Judgment from Torun, and in the Concert of Angels by Hermann Han (cat. no. 16; Fig. 4).

Anton Möller's technology and technique is very similar to the Dutch painting tradition of the end of the 16th and the beginning of the 17th century. The artist was one of the precursors in the use of linen canvas in Gdańsk. Wooden canvas supports made of oak wood should be associated with the Dutch tradition that has been widespread in Gdańsk art since the Middle Ages. The use of coloured grounds and brown underlayer is a part of the new tendency when the white ground was moved away and more inclined towards coloured grounds. The transitional period was the use of white ground and colourful imprimatura, which was rooted in the fifteenth and sixteenth century tradition of painting workshops ${ }^{29}$. Frans Floris (1516-1570) who worked in Antwerp and Liège and who traveled to Rome during his painting activity, is one of the artists who used white chalk-glue ground and brown imprimatura. Dieu rassemblant et protegeant son peuple par la grâce du crucifie and Sainte Famille from the Louvre Museum are the examples of paintings with grey imprimatura. The white imprimatura appears in the painting of Vénus et l'Am$o r^{30}$. These paintings show a warm colour characteristic of Italian painting.

29 Ella Hendriks, “The Use of the Ground Colour”, in Painting in Haarlem 1500-1850: The collection of the Frans Hals Museum, ed. Niklaus Kohler (Ludion: Ultgeverij, 2006), 80, in: Abbie Vandivere, “In Search of van Mander's Primuersel: Intermediate Layers in Early Netherlandish Paintings”, in ICOM-CC Working Group Art Technological Source Research, Vienna, 23-24 September 2010, (Lisbon: Getty Research Institute, 2011), 7, reference 7.

30 Les Archives de la restauration au Centre de recherche et de restauration des musées de France (C2RMF), The report of the analysis of paintings by Frans Floris Dieu rassemblant et protegeant son peuple par la grâce du crucifie (1562) (No. INV 20746, ref. no. C2RMF: F2576), Sainte Famille (No. INV 2796, ref. no. C2RMF: F2578), Vénus et l'Amor (No. INV 28059, ref. no. C2RMF: F2575). 
Similarly, warm colouring of Möller's paintings indicates that he could had been inspired by Italian or Flemish painting with Italian influences and at the same time the hypothesis about his journey to the Netherlands can be confirmed. The white imprimatura was also used by Jan van Scorel (1495-1562) at the Marchiennes Polyptych, which is exhibited at the Chartreuse Museum in Douai, France. Scorel was famous for the use of colourful imprimatura ${ }^{31}$. Möller's technique approaches to the mannerists of the so-called Haarlem school of the end of the 16th and early 17th century in the use of yellow and pink grounds ${ }^{32}$.

The research performed in Gdańsk paintings of the last quarter of the 16th and the first half of the 17th century showed that the workshop of Anton Möller had a great impact on the development of the painting workshop in Pomerania. White ground and grey imprimatura as well as colourful grounds characteristic of the Gdańsk artist were identified, among others, in Gronau's epitaph and in the paintings by Hermann Han and by Isaac van den Blocke. Artists working in this area could be influenced by the painting school of Gdańsk and by Anton Möller's works and they could derive technical achievements directly from the Netherlands.

The dominant pigments in the Möller's painting palette are: lead white, lead-tin yellow, iron yellow and red pigments of natural origin, vermilion, minium, red carmine organic pigment, smalt, natural azurite, iron umber and charcoal. Anton Möller and Isaac van den Blocke as the only Gdańsk artists used ultramarine in their paintings.

The works by Anton Möller are distinguished by the use of bright colours similar to Italian and Flemish paintings. The artist experimented with colour. He used different colours of grounds, imprimatura and brown underpainting to achieve the desired effects, including a white imprimatura to illuminate the surface of the painting, or a pink ground to paint the sky. The composition of the painting was painted with a brown paint, and with a warm shade that gave a warm colour. Anton Möller used strong contrasts of chiaroscuro to paint red robes. He juxtaposed red with the lighter parts painted with a mixture of red and the addition of a large amount of lead white. These treatments were supposed to create an impression of luminosity, which brings the colour of composition closer to Italian painting. Anton

31 Filedt Kok, Halsema-Kubes and Kloek, Kunst voor, 108.

32 Hendriks, “The Use”, 7, reference 7. 
Möller used the painting techniques characteristic of the turn of the 16th and 17th centuries in the European art and belongs to a group of outstanding artists working in Gdańsk.

Transl. Ewa Derkowska-Rybicka, Bożena Szmelter-Fausek

\section{Bibliography}

Cennini, Cennino. Rzecz o malarstwie. Teksty źródłowe do dziejów teorii sztuki, vol. 3, ed. Juliusz Starzyński. Wrocław: Ossolineum, 1955.

Chrościcki, Juliusz A. „'Orfeusz i Eurydyka’ Hansa Vredemana de Vries na tle tradycji ikonograficznej”. In Dwór Artusa w Gdańsku. Sztuka i sztuka konserwacji, Dwór Artusa 17-19 października 2002, ed. Teresa Grzybkowska, Joanna Talbierska, 123-141. Gdańsk: Oficyna Pomorska, 2004.

De Mayerne, Theodore Turque. "Pictoria, Sculptoria, Tinctoria at quae subalternarum atrium, [...]", 1620. In Quellen für Maltechnik während der Renaissance und deren Folgezeit (XVI-XVIII Jahrhundert) in Italien, Spanien, den Niderlanden, Deutschland, Frankreich und England nebst den de Mayerne Manuscript, 3 Teil, ed. Ernst Berger, München: Callwey, 1901.

Doerner, Max. Materiały malarskie i ich zastosowanie. Warszawa: Arkady, 1975.

Drost, Willi. Danziger Malerei vom Mittelalter zum Ende des Barock. Ein Beitrag zur Begründung der Strukturforschung in der Kunstgeschichte. Berlin, Leipzig: Verlag für Kunstwissenschaft, 1938.

Faries, Molly, Christa Steinbüchel, Johan R. J. van Asperen de Boer. "Maarten van Heemskerck and Jan van Scorel's Haarlem Workshop”. In Historical Painting Techniques, Materials, and Studio Practice, ed. Arie Wallert, Erma Hermens, Maria Peek, Marina Del Rey, 135-139. Calif.: Getty Conservation Institute, 1995.

Filedt Kok, Jan P., Willy Halsema-Kubes, Wouter Th. Kloek, Kunst voor de beeldenstorm: Noordnederlandse kunst 1525-1580: Catalogus, 106-116. Amsterdam: Rijksmuseum, 1986.

Flik, Józef, Justyna Olszewska-Świetlik, Adam Cupa, Anna Wypych. „Rysunek w malarstwie sztalugowym - badania reflektografii w podczerwieni”. In: Księga pamiątkowa ofiarowana profesorowi Wiesławowi Domasłowskiemu, ed. Bożena Soldenhoff, 47-81. Toruń: Wydawnictwo UMK, 2002.

Flik, Józef, Justyna Olszewska-Świetlik. Tryptyk „Sąd Ostateczny” Hansa Memlinga $z$ Muzeum Narodowego w Gdańsku. Technologia i technika malarska, Toruń: Wydawnictwo UMK, 2005.

Gosieniecka, Anna. Wzory graficzne w malarstwie pomorskim drugiej połowy XVI i początków XVII wieku, „Ze studiów nad sztuką XVI w. na Śląsku i w krajach sąsiednich”, ed. Bożena Steinborn, 111-132. Wrocław: Muzeum Śląskie, 1968. 
Haneca, Kristof, Tomasz Ważny, Hans Beeckman, Joris van Acker, “Provenancing Baltic Timber from Art Historical Objects: Success and Limitations”. Journal of Archeological Science, 32, no. 2 (2005): 206-271.

Hendriks, Ella, “The Use of the Ground Colour”, in Painting in Haarlem 1500-1850: The collection of the Frans Hals Museum, ed. Niklaus Kohler, (Ludion: Ultgeverij, 2006), 80. In: Abbie Vandivere, “In Search of van Mander's Primuersel: Intermediate Layers in Early Netherlandish Paintings”. In: ICOM-CC Working Group Art Technological Source Research, Vienna, 23-24 September 2010, (Lisbon: Getty Research Institute, 2011), 7, reference 7, access 27.03.2017, http://www.icom-cc-publications-online.org/PublicationDetail.aspx?cid=05b30243-1d2d-4d09-b8e8-3ef281cb3672.

Katalog zabytków sztuki w Polsce, vol. 5 Województwo gdańskie, no. 2 Puck, Żarnowiec i okolice, ed. Barbara Rol, , Strzelecka, Iwona, Warszawa: Wydawnictwo Artystyczne i Filmowe, 1989.

Kębłowski, Janusz S., „’'Sąd Ostateczny’ Antoniego Möllera na tle tradycji tematu w XV i XVI wieku”. In: Dwór Artusa w Gdańsku. Sztuka i sztuka konserwacji. Materiały z konferencji naukowej, Gdańsk, Dwór Artusa, 17-19 października 2002, red. T. Grzybkowska, J. Talbierska, Warszawa 2004, 143.

Labuda, Teresa, „Sąd Ostateczny” Antoniego Möllera z Dworu Artusa w Gdańsku: problemy ikonografii, Gdańskie Studia Muzealne, Tom 4 (1985):_220-221.

Morka, Mieczysław, „Ukrzyżowanie Christopha Schwarza - polskie warianty”, Rocznik Historii Sztuki 20 (1994): 87-108.

Olszewska-Świetlik, Justyna, Technologia i technika malarska wybranych nowożytnych epitafiów z Bazyliki Mariackiej w Gdańsku. Toruń: Wydawnictwo Naukowe UMK, 2009.

“O obrazach w ołtarzu głównym w kościele w czasach powojennych”, Oficjalna Strona Łęgowa 10, 2007, Access 5 June 2017 http://www.legowo.schoolpage.pl/2007-4.html. Pasierb, Janusz, Malarz gdański Herman Han. Warszawa: PWN, 1974.

Pięta, Ewa, Edyta Proniewicz, Bożena Szmelter-Fausek, Justyna Olszewska-Świetlik, Leonard M. Proniewicz, "Micro-Raman Spectroscopy Analysis of $17^{\text {th }}$ Century Panel Painting ‘Servilius Appius’ by Isaac van den Blocke”, Journal of Raman Spectroscopy 45, no. 11 (2014): 1019-1025.

Rouba, Bogumiła J. „Płótna jako podobrazia malarskie”. Ochrona Zabytków 3-4 (1985): 37-57.

Roznerska, Maria. Techniki malarskie “małych mistrzów holenderskich” XVII w. Toruń: Wydawnictwo UMK, 1991.

Schmid, Bernhard. Die Bau- und Kunstdenkmäler der Provinz Westpreußen, Bd. IV Marienburg, H 14 Kreis Marienburg. Danzig: Verlag des Provinzial-Verbandes von Westpreusen. Kommissionsverlag von A. W. Kafemann G. M. B. H., 1919.

Slánský, Bohuslav. Technika malarstwa, vol. 2. trans. Stanisław Gawłowski, Warszawa: Arkady, 1965. 
Szmelter-Fausek, Bożena, Gdański warsztat malarski ostatniej ćwierci XVI i pierwszej połowy XVII w. na przykładzie twórczości Antona Möllera (1563/5-1611) i Hermanna Hana (1580-1627/8), PhD, Nicolaus Copernicus University, Toruń 2013.

Szmelter-Fausek, Bożena, Justyna Olszewska-Świetlik, Blue Pigments in Blue and Purple Painting Layers of Gdańsks' Paintings of the Mid-16th to the End of the 18th Century, "Colour research and application", 41, no 3 (2016): 270-275

Szmelter-Fausek, Bożena, Justyna Olszewska-Świetlik, “The Study on Technology and Technique of the Painting 'Last Judgement' from St. James Church in Torun'”. In: Interdisciplinary Research on the Works of Art, ed. Olszewska-Świetlik, Justyna, Joanna A. Arszyńska, Bożena Szmelter-Fausek, 209-217. Toruń: Wydawnictwo Naukowe UMK, 2012.

Szmelter-Fausek, Bożena, “Wybrane obrazy ołtarzowe Hermanna Hana (1580-c. 1628) - zagadnienia technologiczne i konserwatorskie”. In Історія релігій в Україні, том II, 609-616. Львів: Львівський музей історії релігії 2012.

Szolginia, Barbara, Teofil Dąbrowski. Konserwacja obrazu H. Hana „Koronacja NMP” z Głównego Ołtarza Katedry w Pelplinie, dokumentacja prac konserwatorskich, Gdańsk 1957, Wojewódzki Urząd Ochrony Zabytków, sign. ZR/113/1, typescript.

The report of the analysis of paintings by Frans Floris Dieu rassemblant et protegeant son peuple par la grâce du crucifie (1562) (No. INV 20746, ref. no. C2RMF: F2576), Sainte Famille (No. INV 2796, ref. no. C2RMF: F2578), Vénus et l'Amor (No. INV 28059, ref. no. C2RMF: F2575).

Tylicki, Jacek. Rysunek gdański ostatniej ćwierci XVI and pierwszej połowy XVII wieku. Toruń: Wydawnictwo UMK, 2005.

Tylicki, Jacek. “Sztuka Prus Królewskich. Malarstwo i rysunek”. In: Prusy Królewskie. Społeczeństwo, kultura, gospodarka 1454-1772, ed. Edmund Kizik, 309-370. Gdańsk: Muzeum Narodowe w Gdańsku, 2012.

Vandivere, Abbie. “In Search of van Mander's Primuersel: Intermediate Layers in Early Netherlandish Paintings”. In: ICOM-CC Working Group Art Technological Source Research. Lisbon: Getty Research Institute, 2011, access 27.03.2017, http://www. icom-cc-publications-online.org/PublicationDetail.aspx?cid=05b30243-1d2d-4d09-b8e8-3ef281cb3672.

Voss, Johanness. „Rysunki warsztatowe późnośredniowiecznych rzeźbiarzy”. In: Od badań do konserwacji, 123-131. Toruń: Wydawnictwo UMK, 2002. 


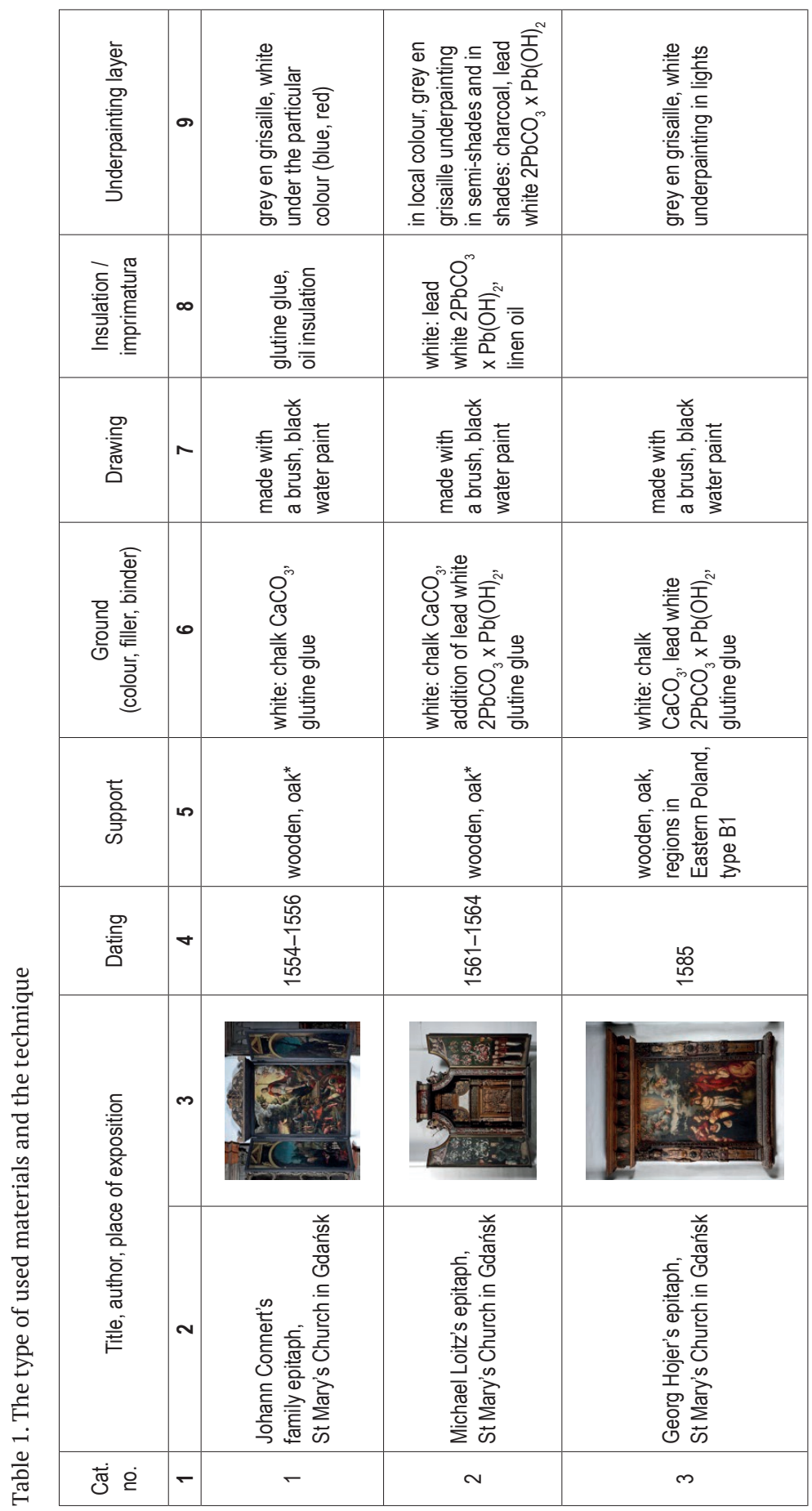




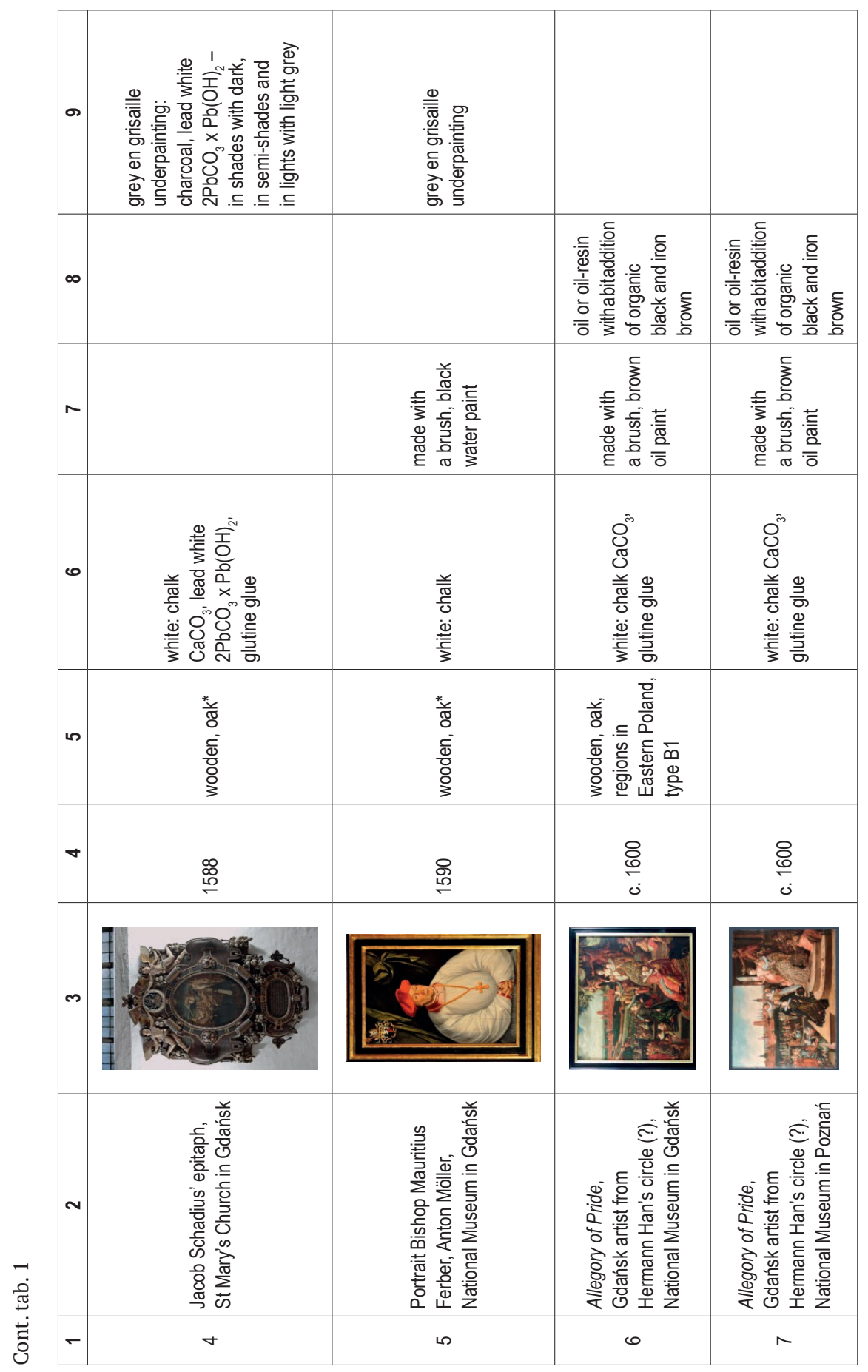




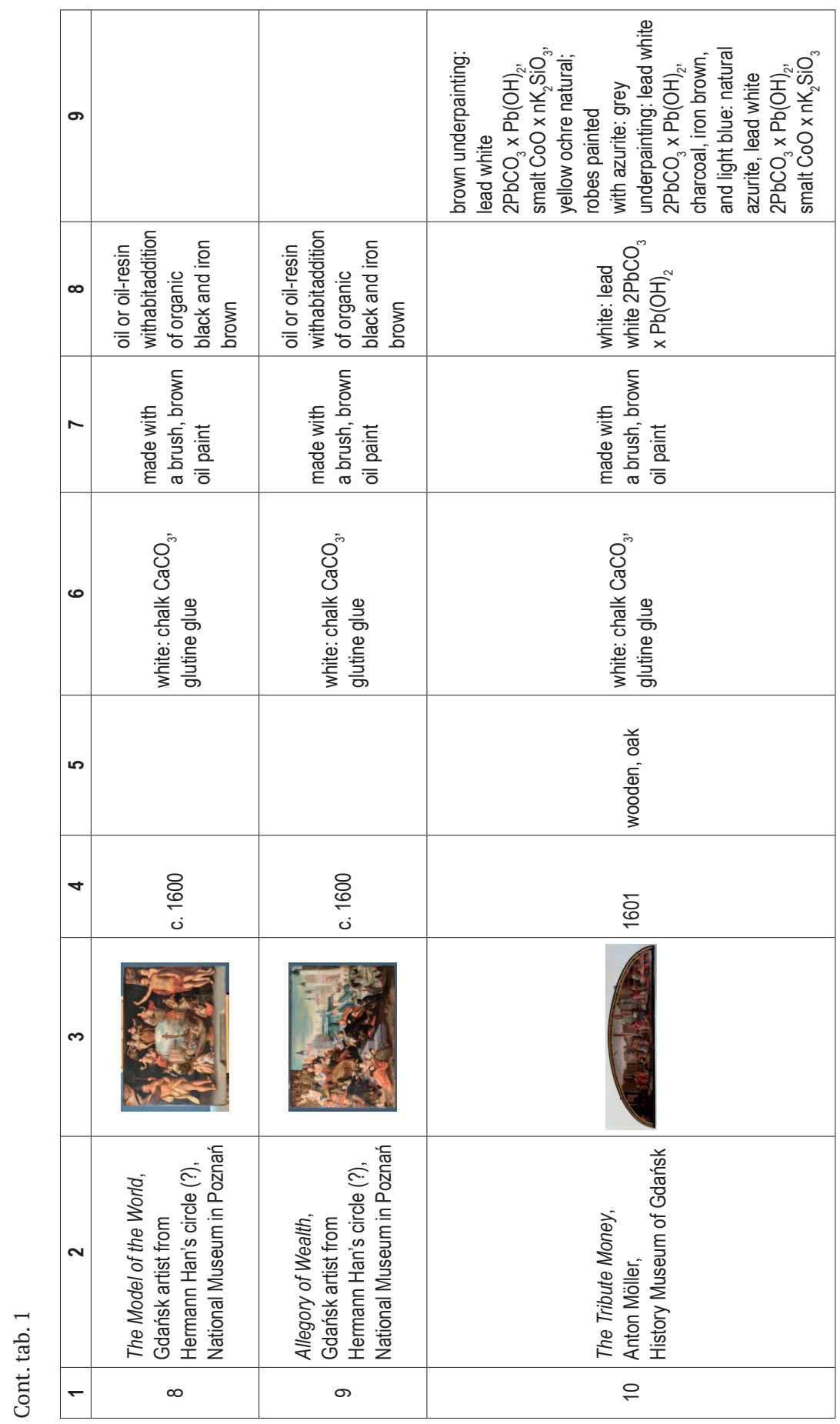




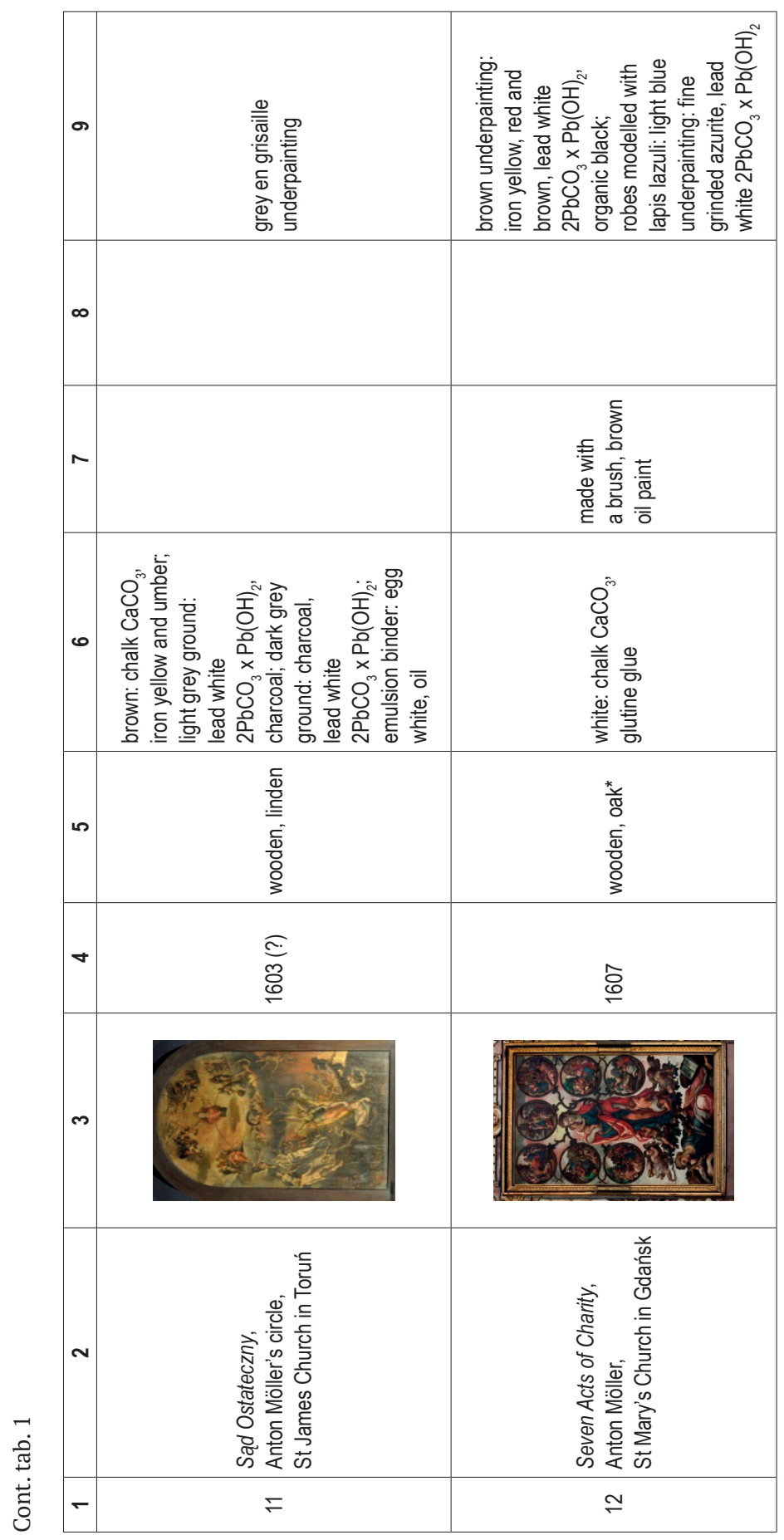




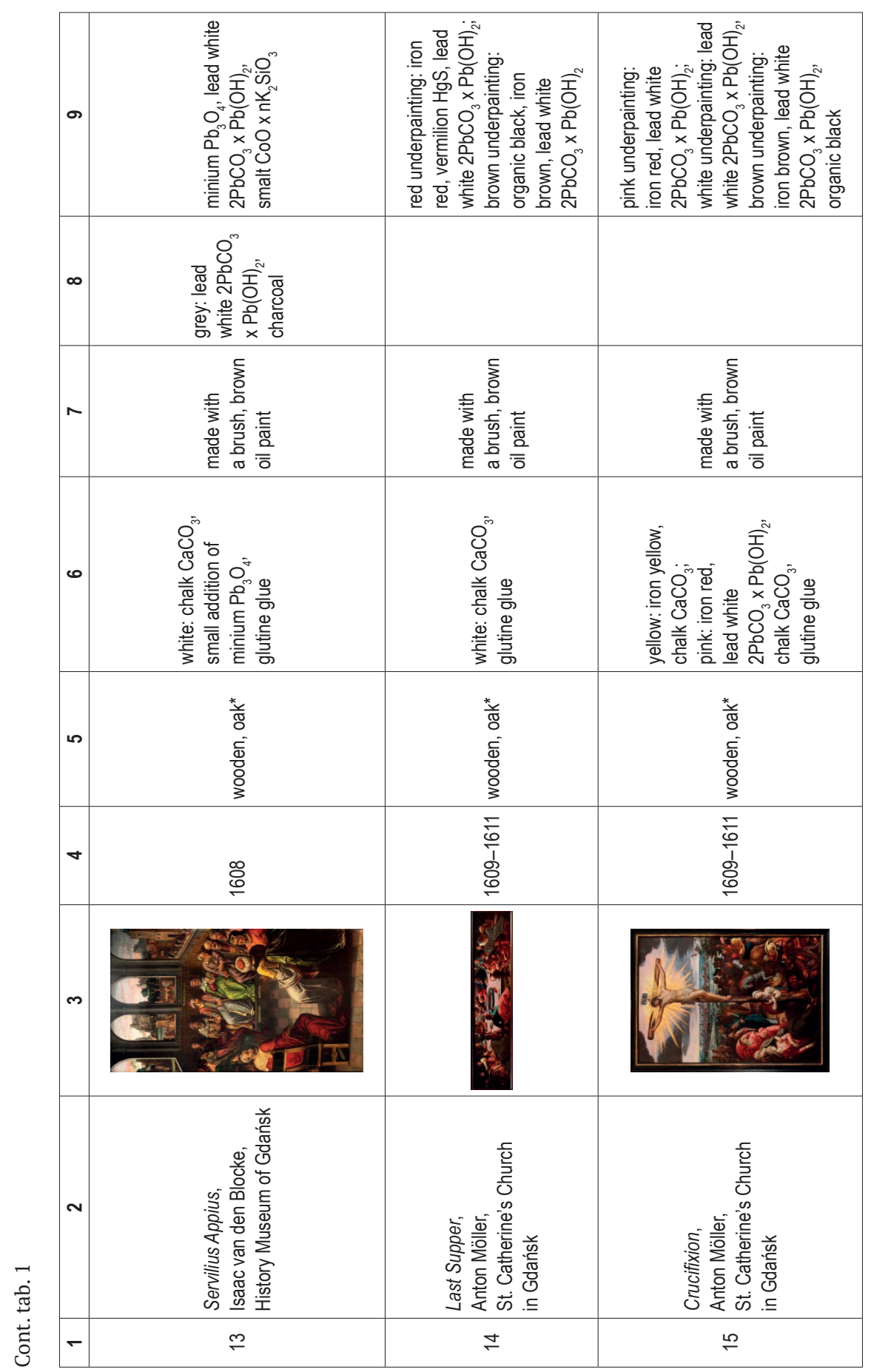




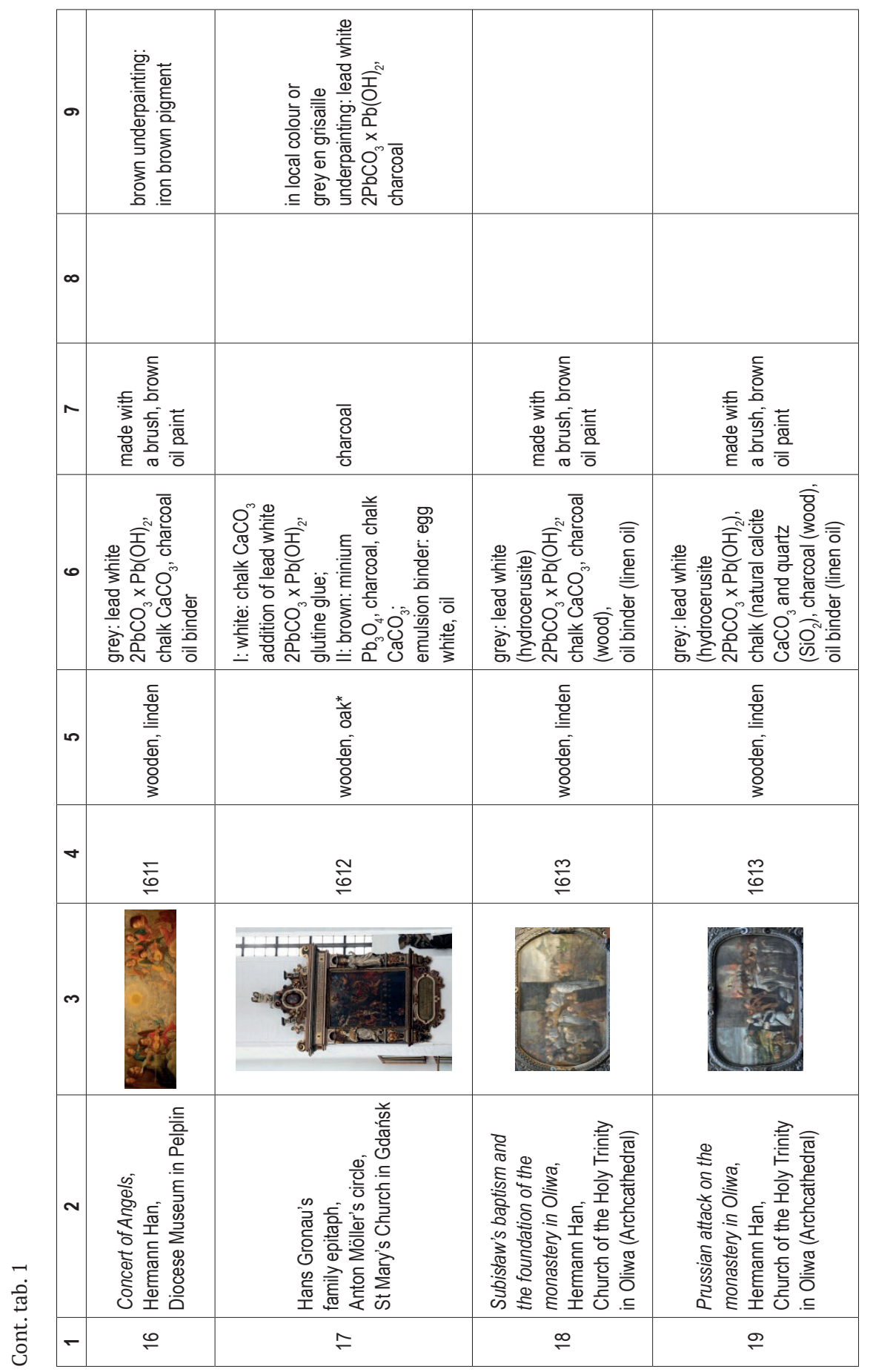




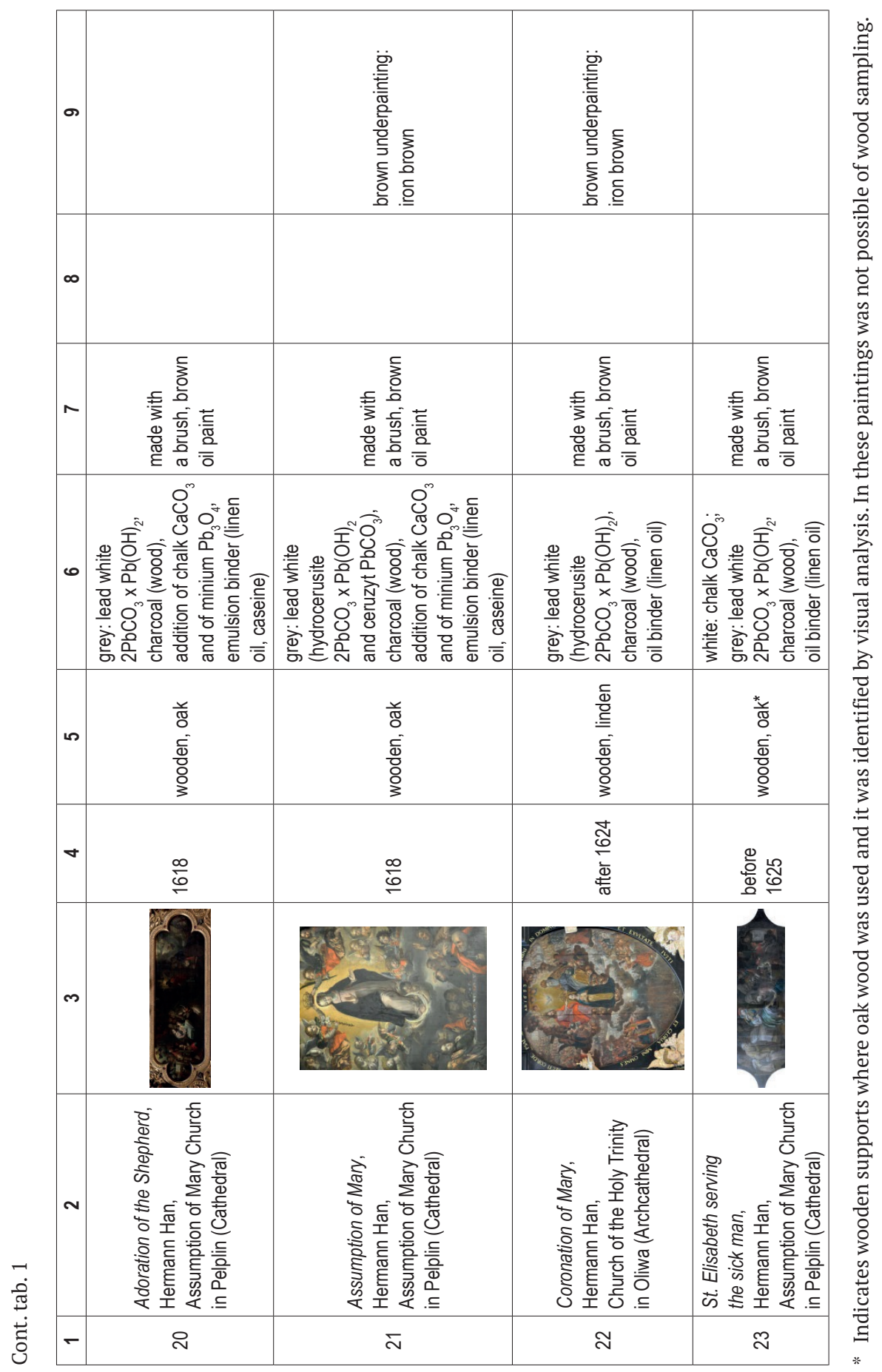




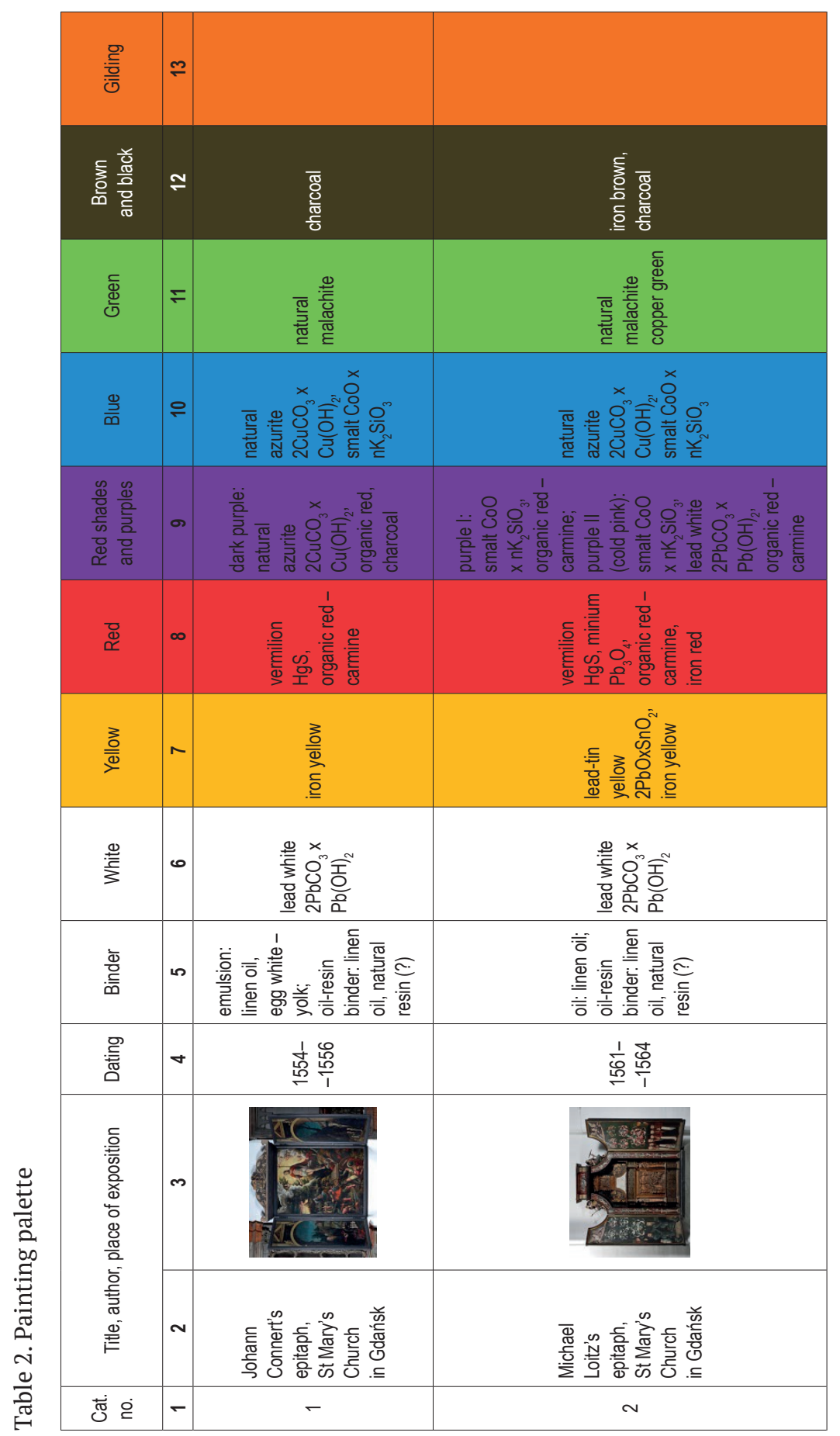




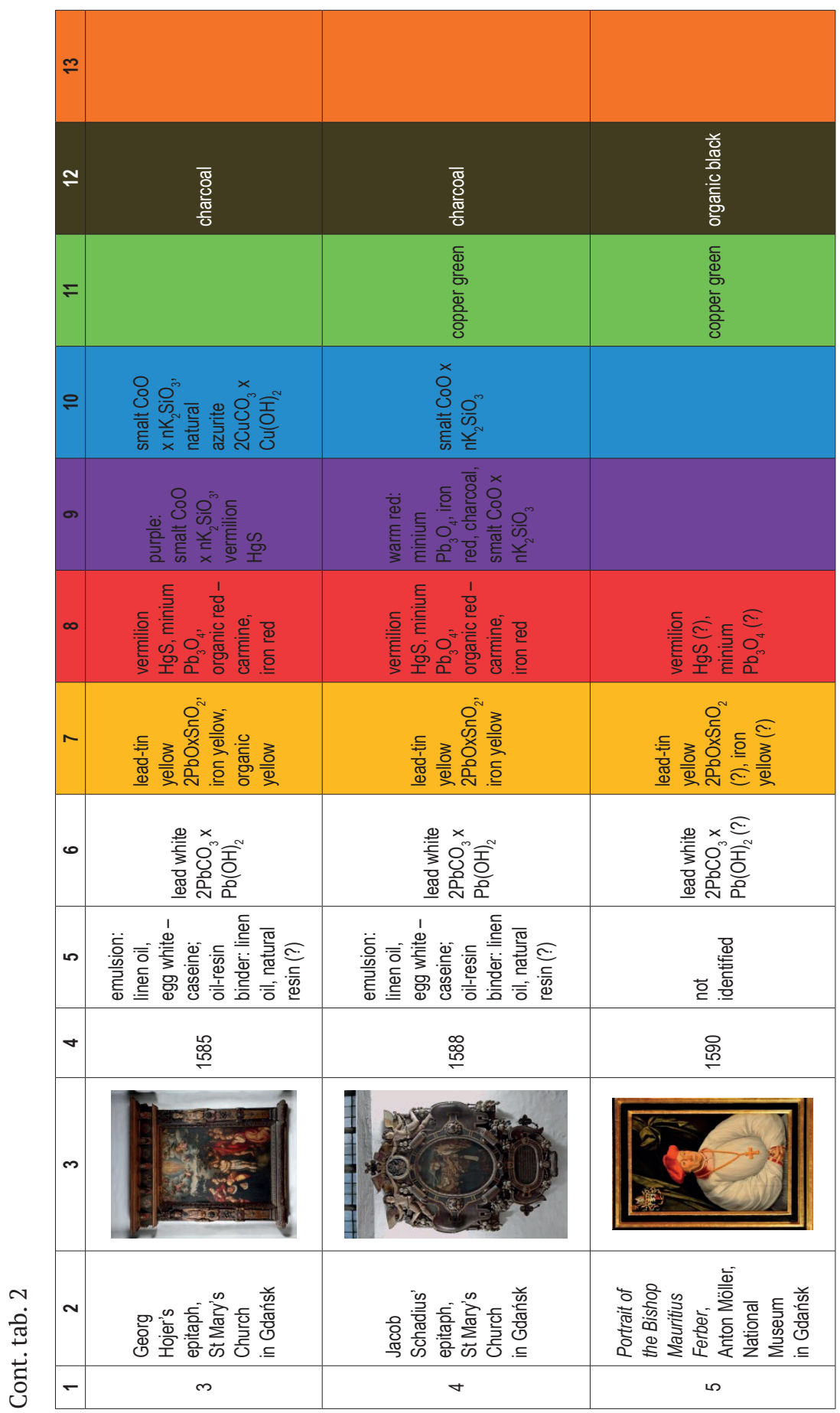




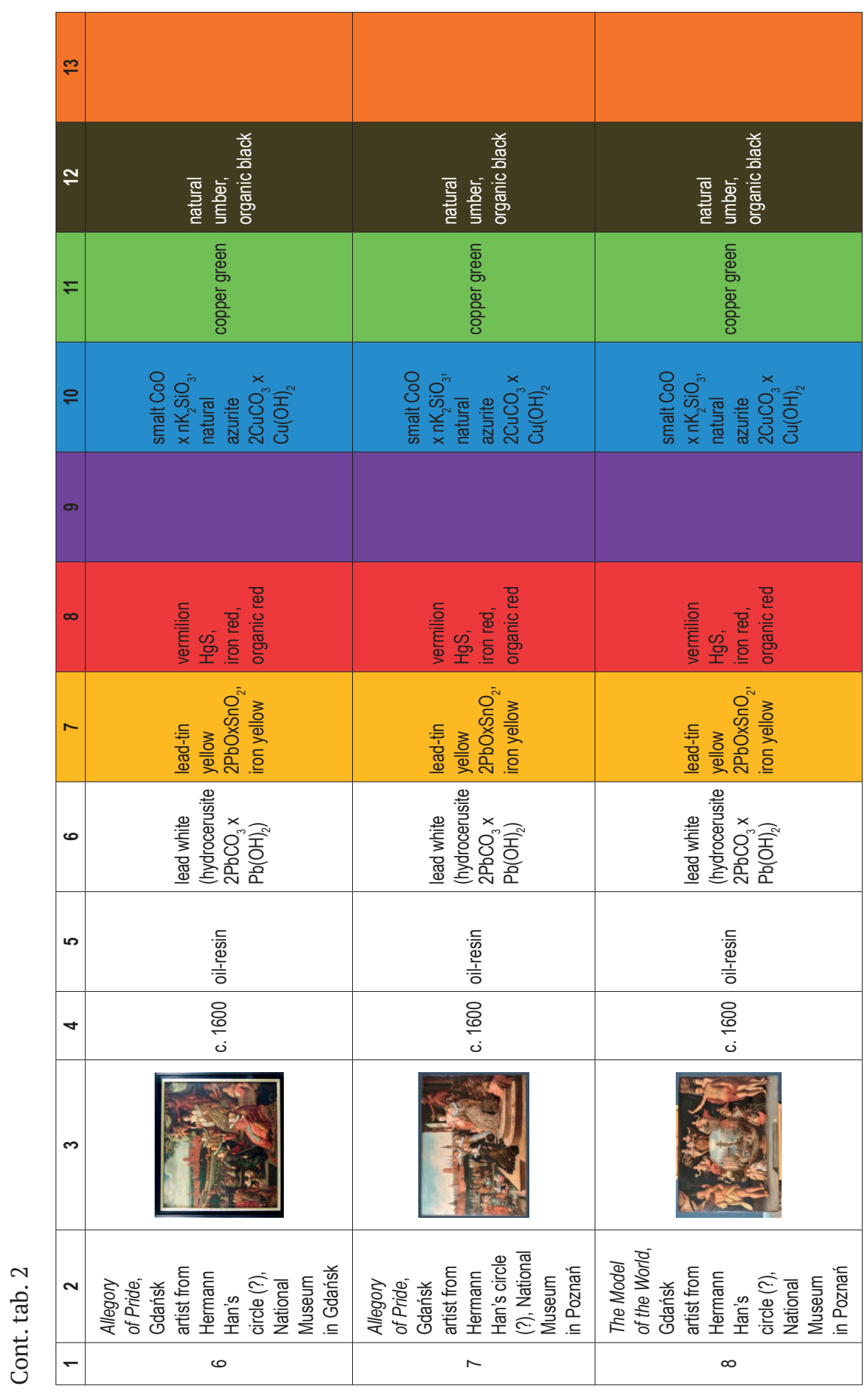




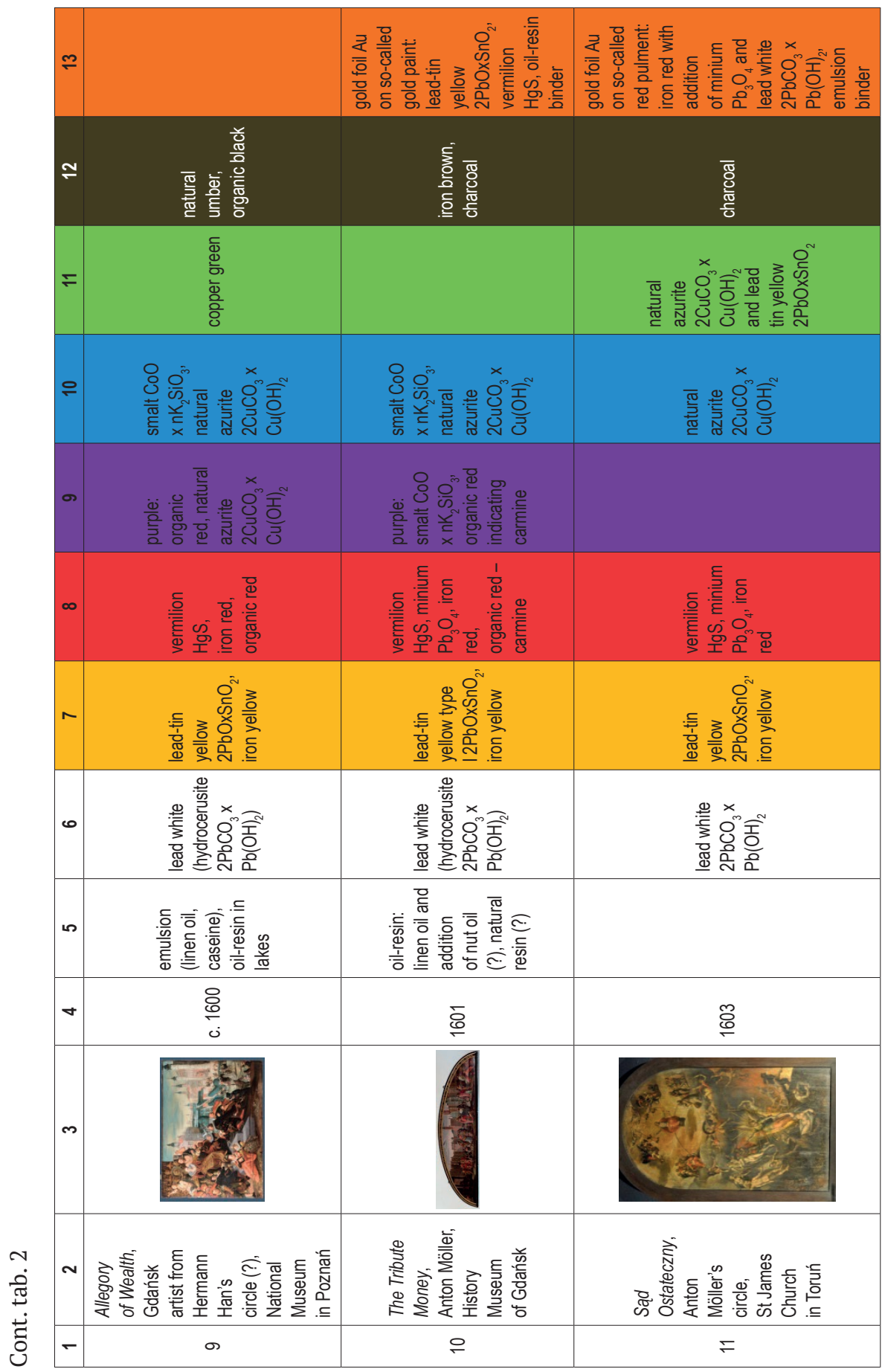




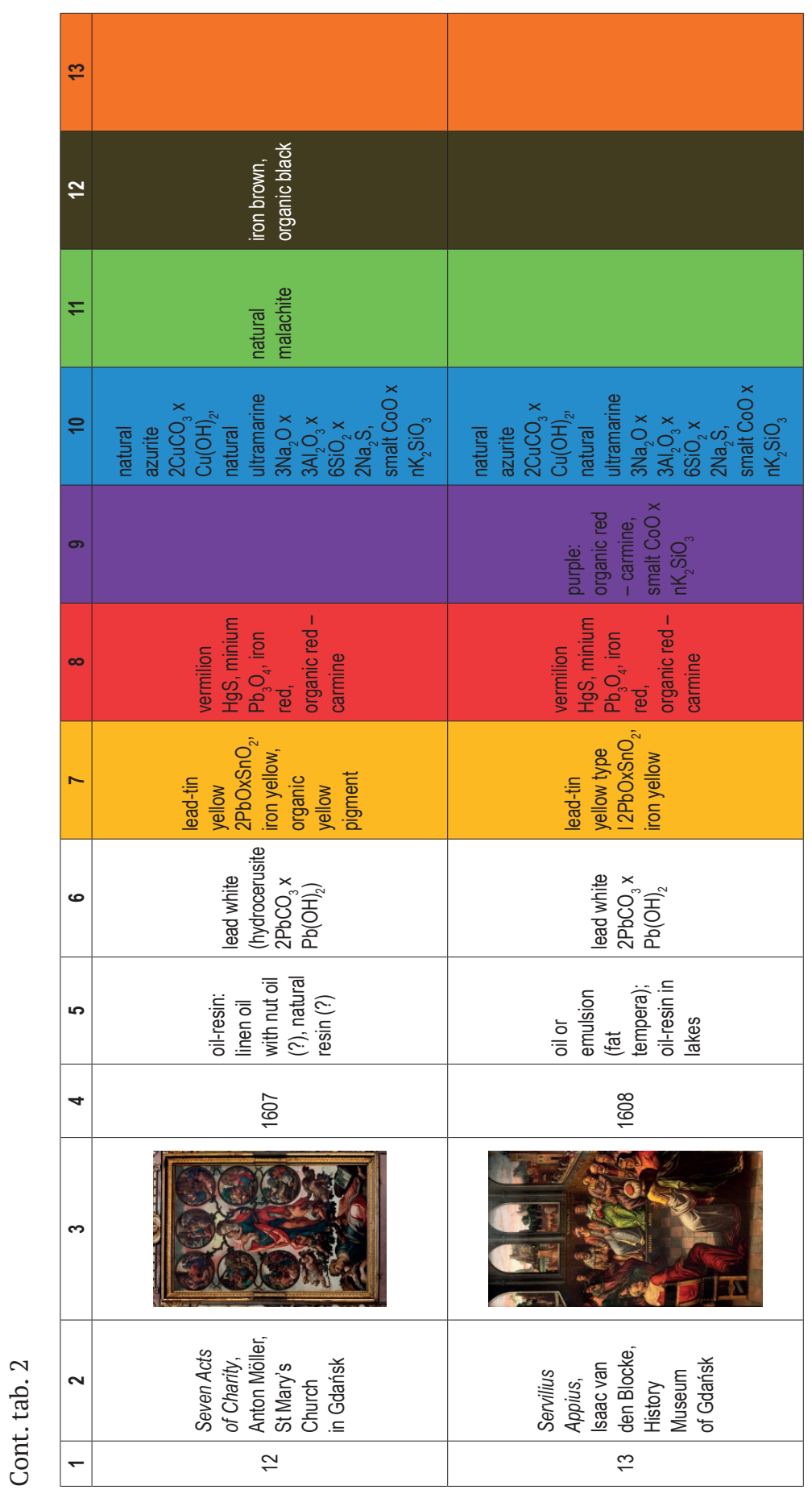




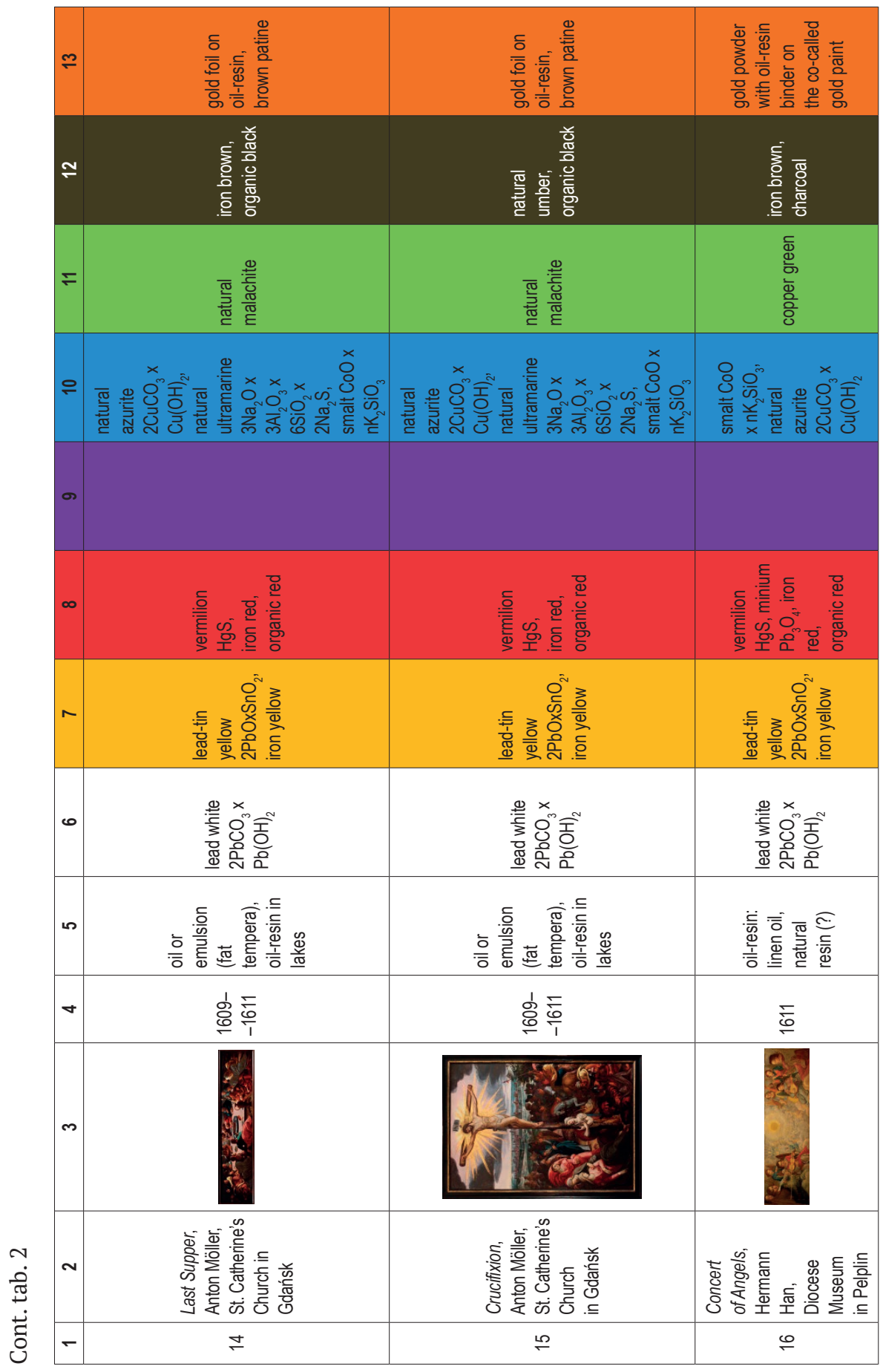




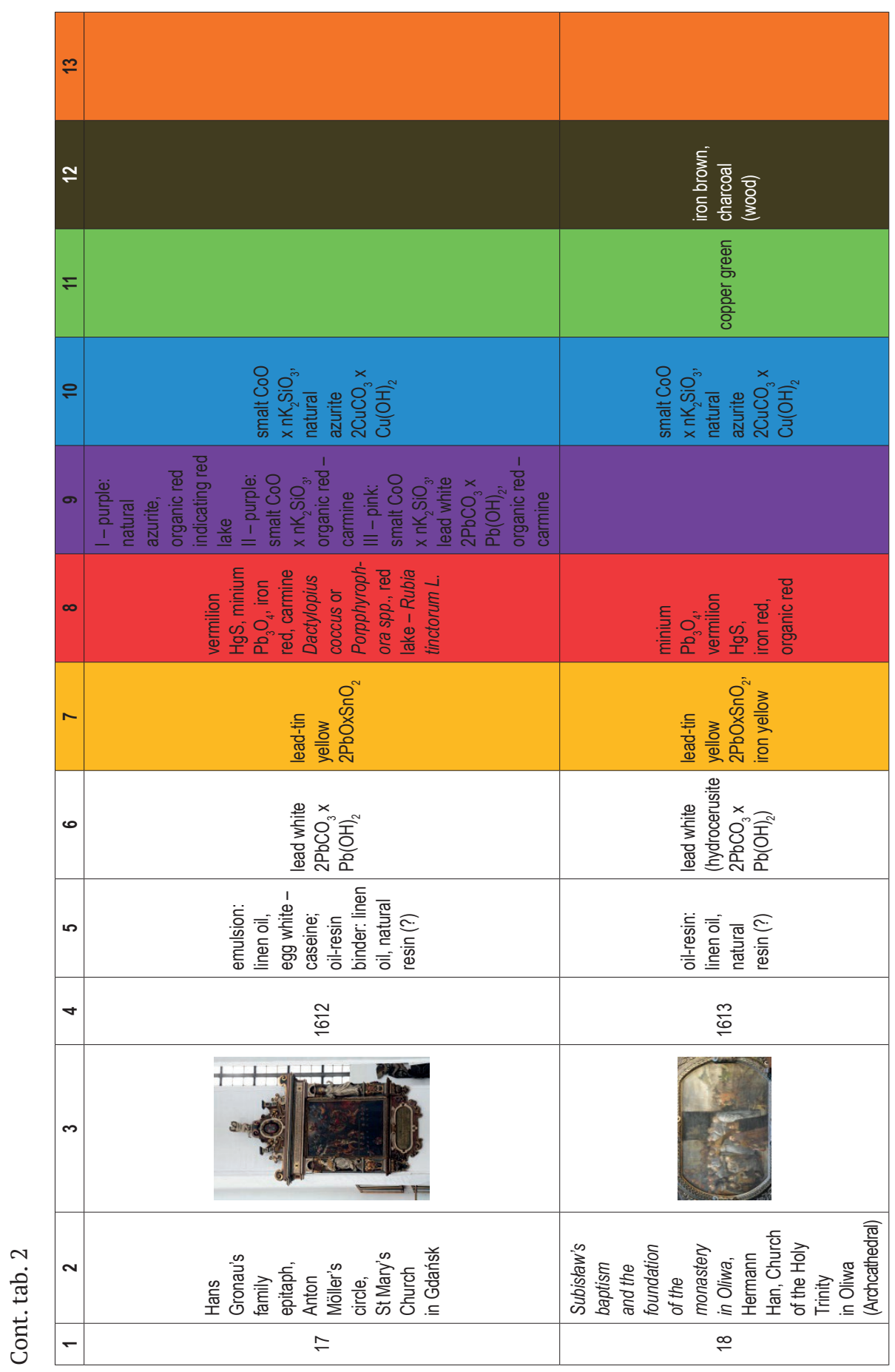




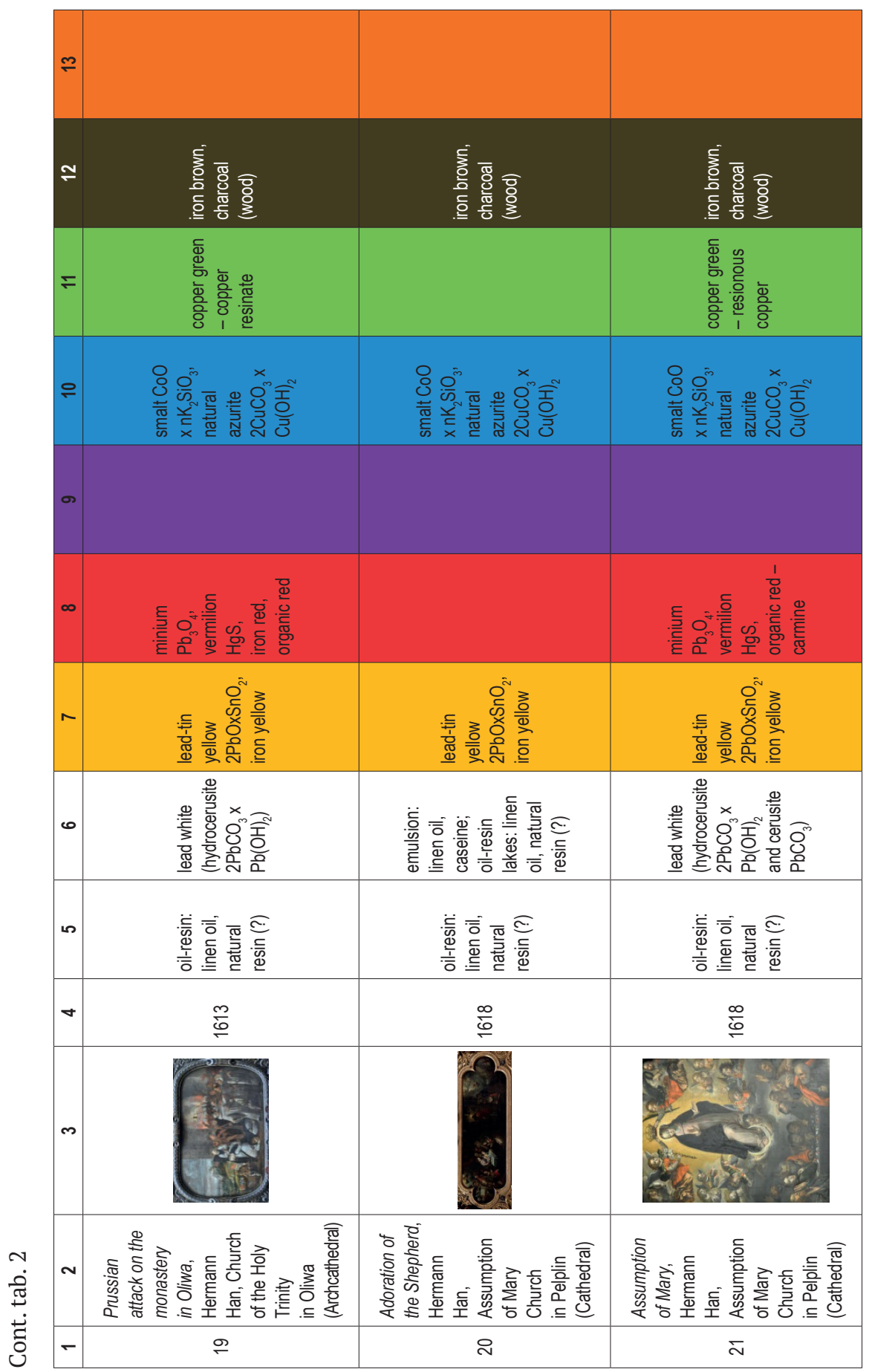




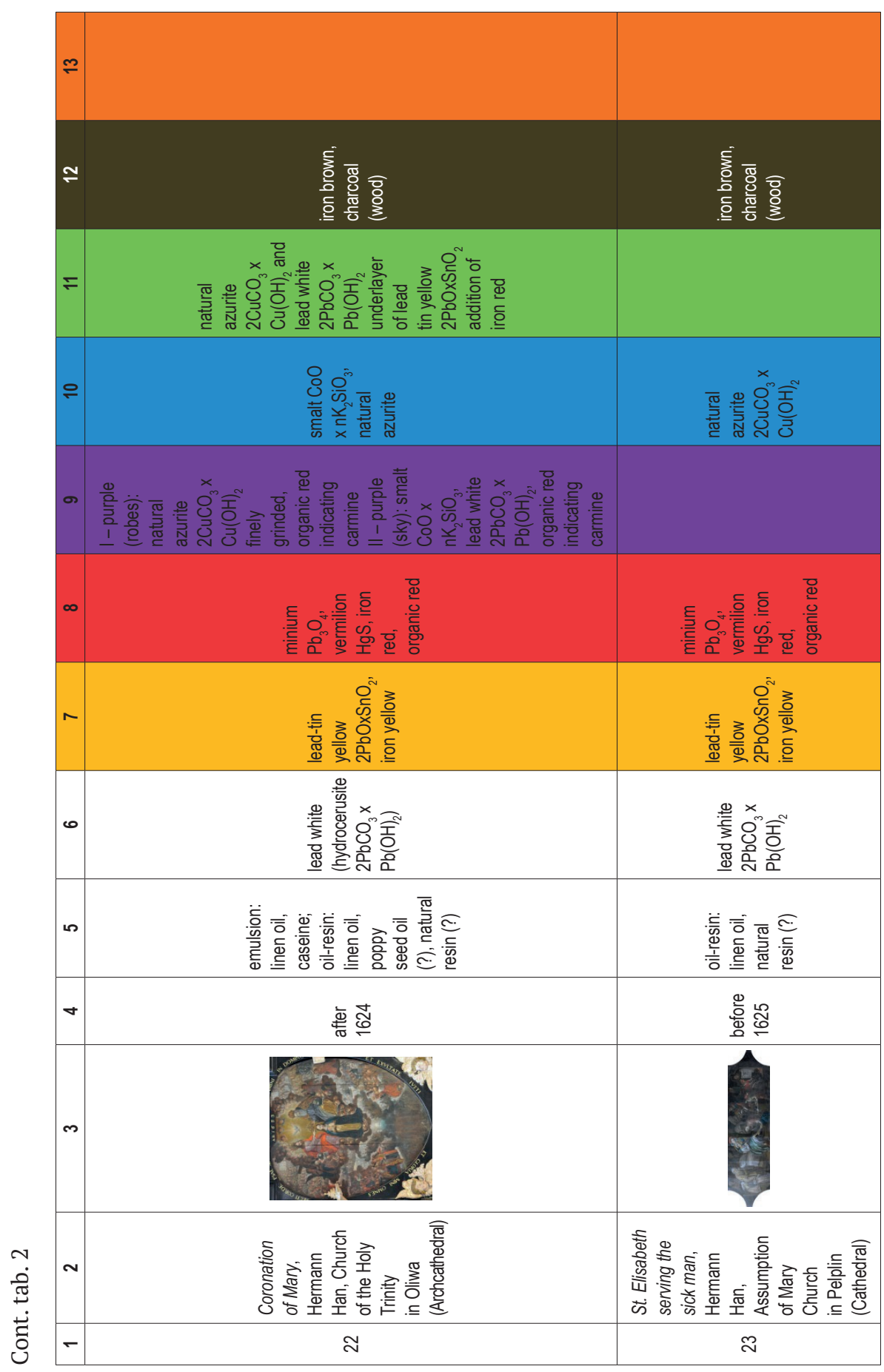



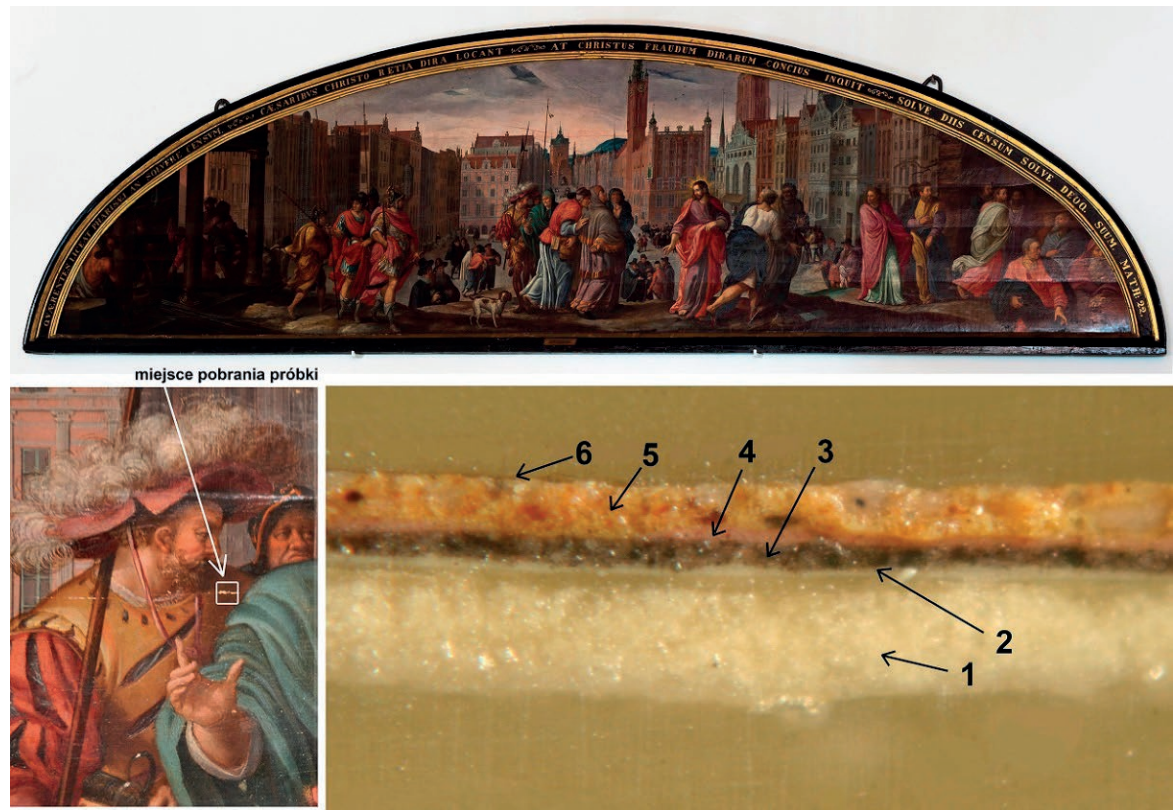

Fig. 1. The Tribute Money, Anton Möller, 1601. Cross-section of the sample of yellow robe. Photography under the VIS. Photo by Andrzej Skowroński and Zuzanna Rozłucka

1 - white ground: chalk $\mathrm{CaCO}_{3} ; 2$ - white imprimatura: lead white $2 \mathrm{PbCO}_{3} \times \mathrm{Pb}(\mathrm{OH})_{2}$; 3 - brown underpainting: iron red hematyt $\mathrm{Fe}_{2} \mathrm{O}_{3}$, lead white $2 \mathrm{PbCO}_{3} \times \mathrm{Pb}(\mathrm{OH})_{2}$, organic black; 4 - pink underpainting: vermilion $\mathrm{HgS}$, lead white $2 \mathrm{PbCO}_{3} \times \mathrm{Pb}(\mathrm{OH})_{2} ; 5$ - yellow

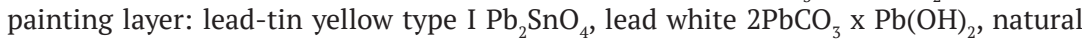
azurite $2 \mathrm{CuCO}_{3} \times \mathrm{Cu}(\mathrm{OH})_{2} ; 6$ - egg white varnish 

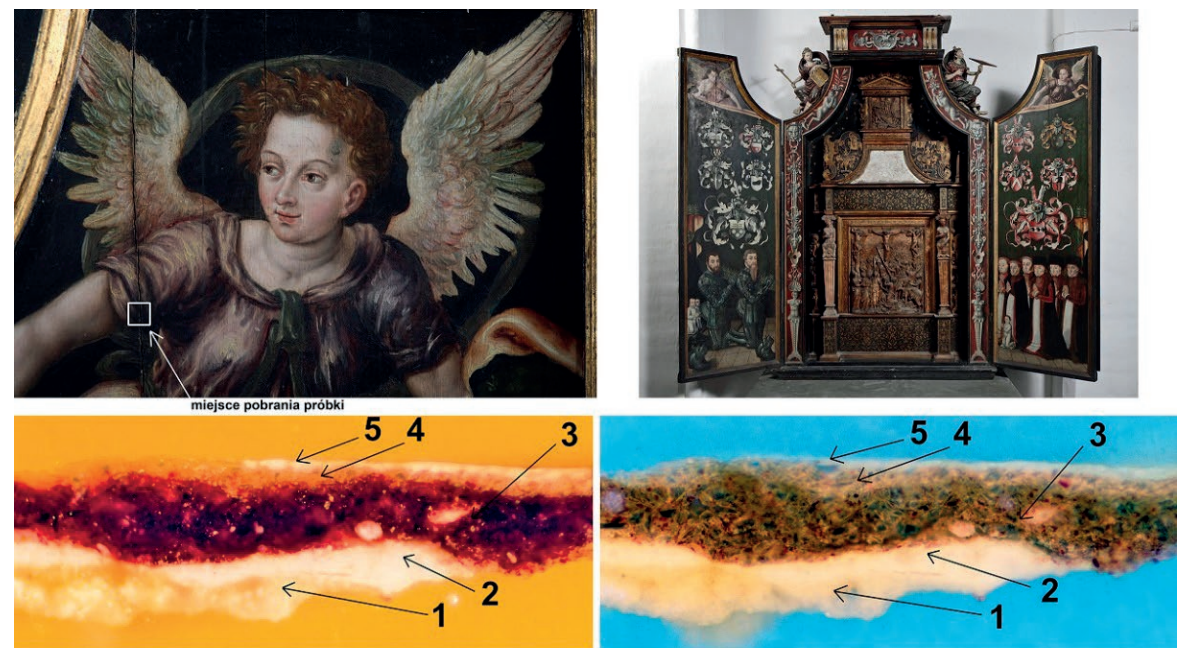

Fig. 2. Michael Loitz's epitaph, 1561-1564. Cross-section of a sample of purple robe. Photography under the VIS and UV. Photo by Andrzej Skowroński and Zuzanna Rozłucka

1 - ground: chalk $\mathrm{CaCO}_{3} ; 2$ - white imprimatura: lead white $2 \mathrm{PbCO}_{3} \times \mathrm{Pb}(\mathrm{OH})_{2} ; 3$ - purple painting layer: organic red - carmine, smalt $\mathrm{CoO} \times \mathrm{nK}_{2} \mathrm{SiO}_{3}$; red painting layer - organic red - carmine, smalt $\mathrm{CoO} \times \mathrm{nK}_{2} \mathrm{SiO}_{3} ; 5$ - varnish 

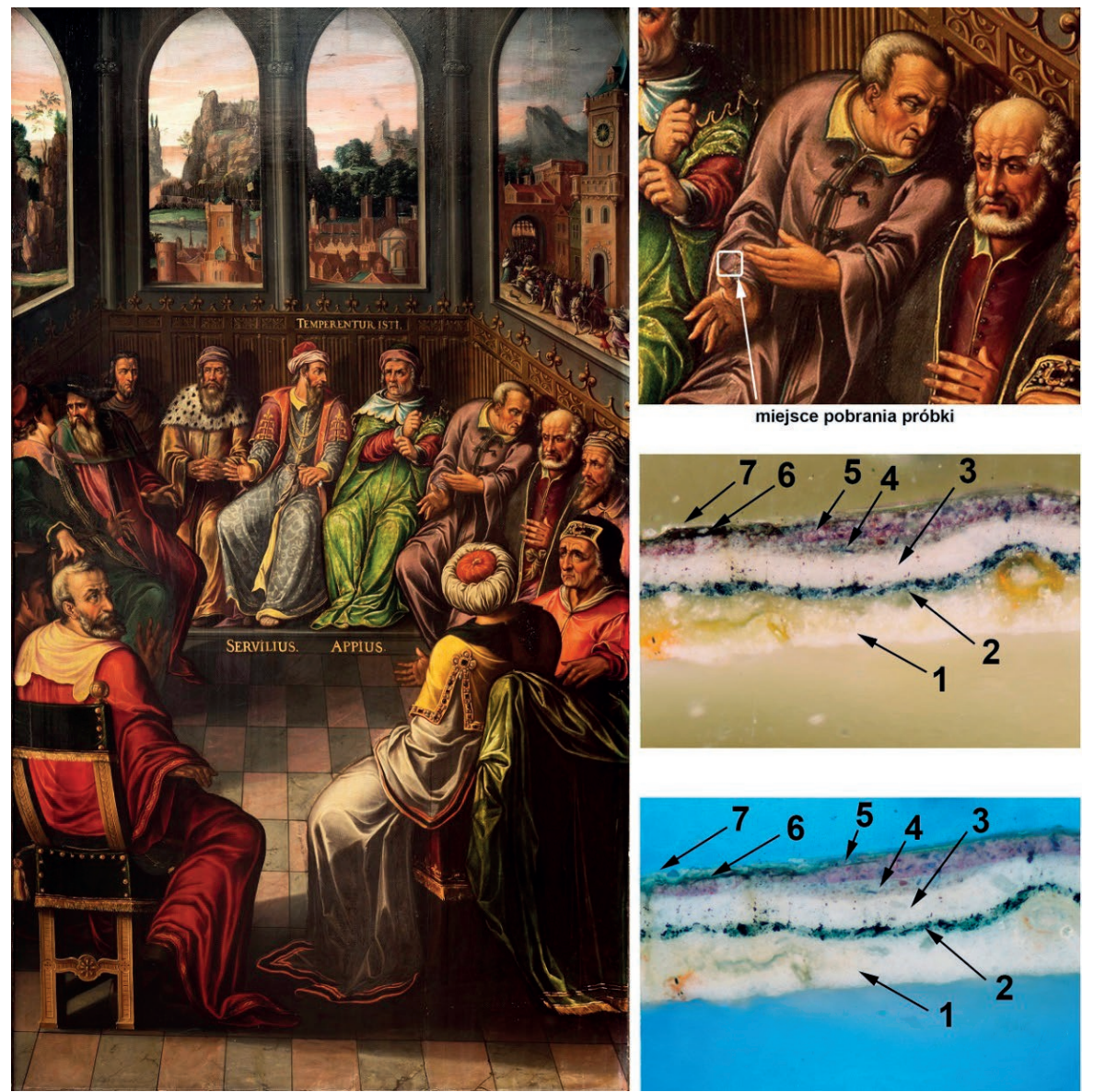

Fig. 3. Servilius Appius, Isaac van den Blocke, 1608. Cross-section of a sample of purple robe. Photography under the VIS and UV. Photo by Andrzej Skowroński and Zuzanna Rozłucka

1 - ground: chalk $\mathrm{CaCO}_{3} ; 2$ - grey imprimatura: charcoal, lead white $2 \mathrm{PbCO}_{3} \times \mathrm{Pb}(\mathrm{OH})_{2}$; 3 - white underpainting: lead white $2 \mathrm{PbCO}_{3} \times \mathrm{Pb}(\mathrm{OH})_{2} ; 4$ - purple and blue painting layer: smalt $\mathrm{CoO} \times \mathrm{nK}_{2} \mathrm{SiO}_{3}$, organic red indicating carmine; 5 - purple painting layer - organic red indicating carmine, smalt $\mathrm{CoO} \times \mathrm{nK}_{2} \mathrm{SiO}_{3} ; 6$ - red lake: organic red indicating carmine; 7 - varnish 


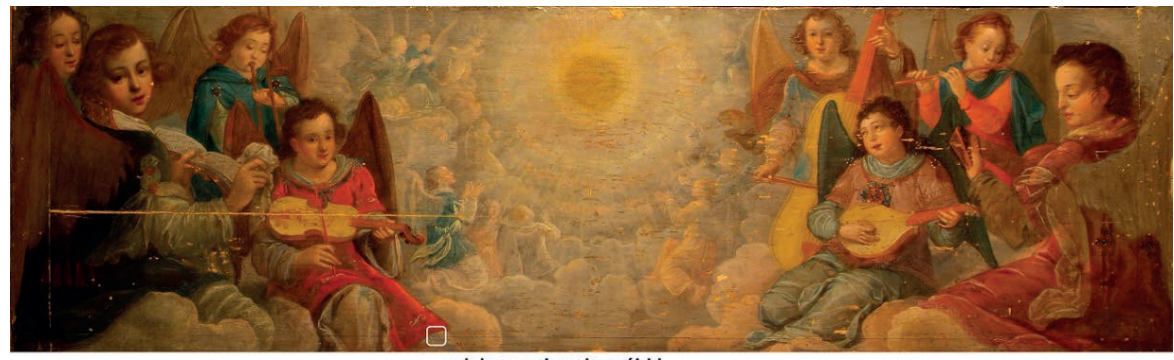

miejsce pobrania próbki

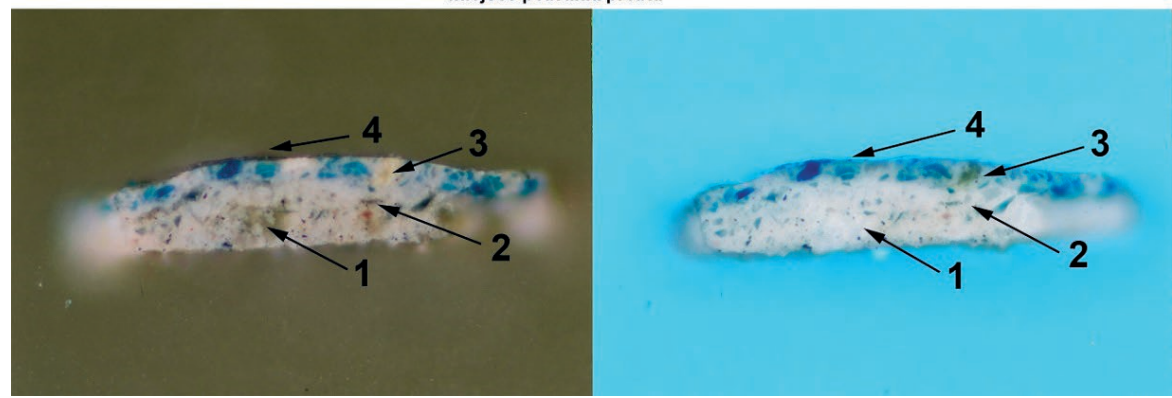

Fig. 4. Concert of Angels, Hermann Han, 1611. Cross-section of a sample of blue robe. Photography under the VIS and UV. Photo by Adam Cupa and Zuzanna Rozłucka

1- grey ground: lead white $2 \mathrm{PbCO}_{3} \times \mathrm{Pb}(\mathrm{OH})_{2}$, chalk $\mathrm{CaCO}_{3}$, charcoal; 2 - light blue painting layer: smalt $\mathrm{CoO} \times \mathrm{nK}_{2} \mathrm{SiO}_{3}$, lead white $2 \mathrm{PbCO}_{3} \times \mathrm{Pb}(\mathrm{OH})_{2} ; 3$ - blue painting layer: natural azurite $2 \mathrm{CuCO}_{3} \times \mathrm{Cu}(\mathrm{OH})_{2}$, lead white $2 \mathrm{PbCO}_{3} \times \mathrm{Pb}(\mathrm{OH})_{2}$, lead-tin yellow $2 \mathrm{PbO} \times \mathrm{SnO}_{2} ; 4$ - secondary varnish 

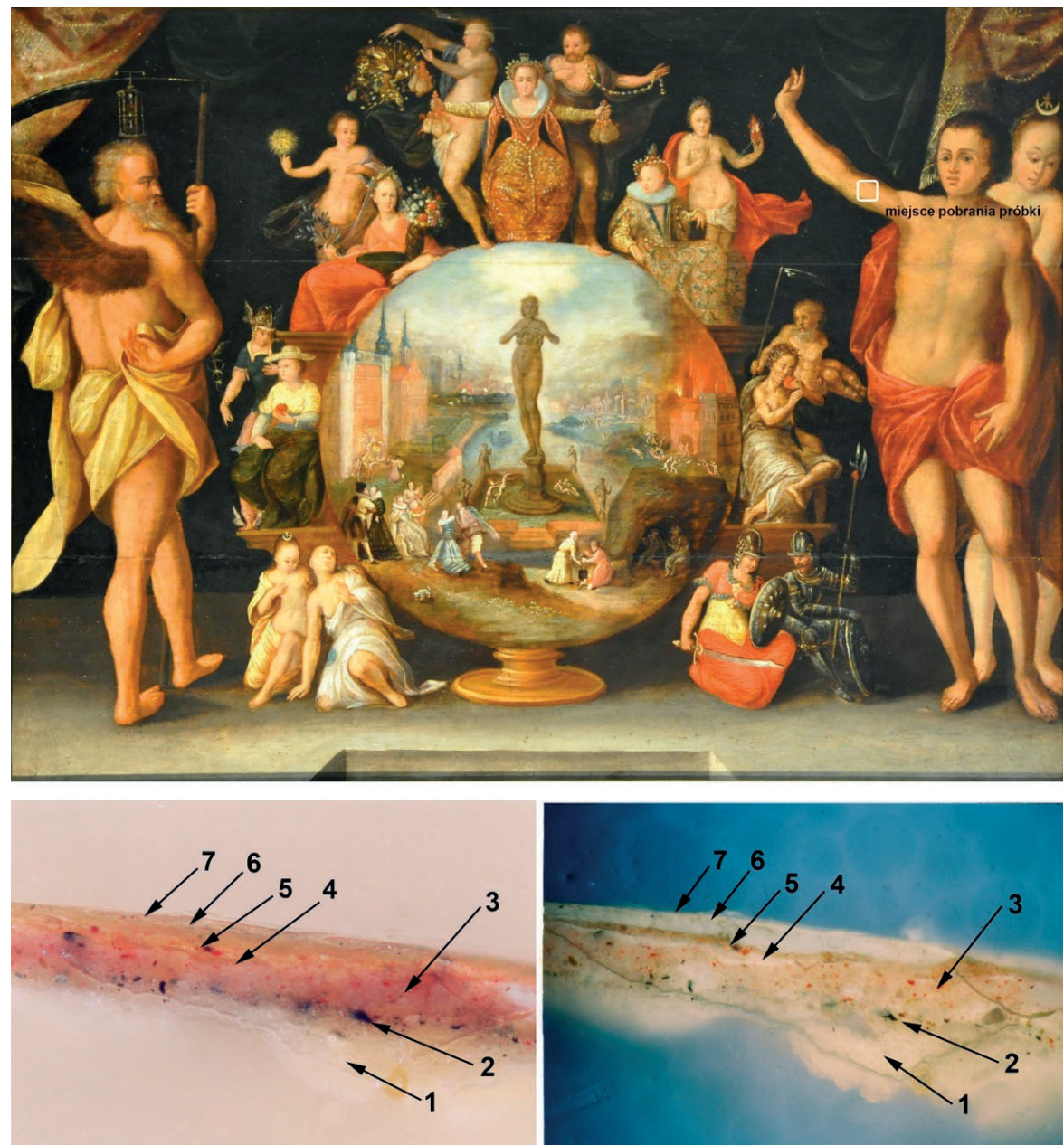

Fig. 5. The Model of the World, Gdańsk artist from Hermann Han's circle (?), c. 1600. Cross-section from the complexion. Photography under the VIS and UV. Photo by Bożena Szmelter-Fausek and Zuzanna Rozłucka

1 - white ground: chalk $\mathrm{CaCO}_{3} ; 2$ - brown underpainting: iron brown pigment, charcoal; 3 - pink painting layer: vermilion $\mathrm{HgS}$, lead white $2 \mathrm{PbCO}_{3} \times \mathrm{Pb}(\mathrm{OH})_{2}$, charcoal; 4 - varnish; 5 - pink painting layer: vermilion $\mathrm{HgS}$, lead white $2 \mathrm{PbCO}_{3} \times \mathrm{Pb}(\mathrm{OH})_{2}$, charcoal; 6 - varnish; 7 - secondary varnish 


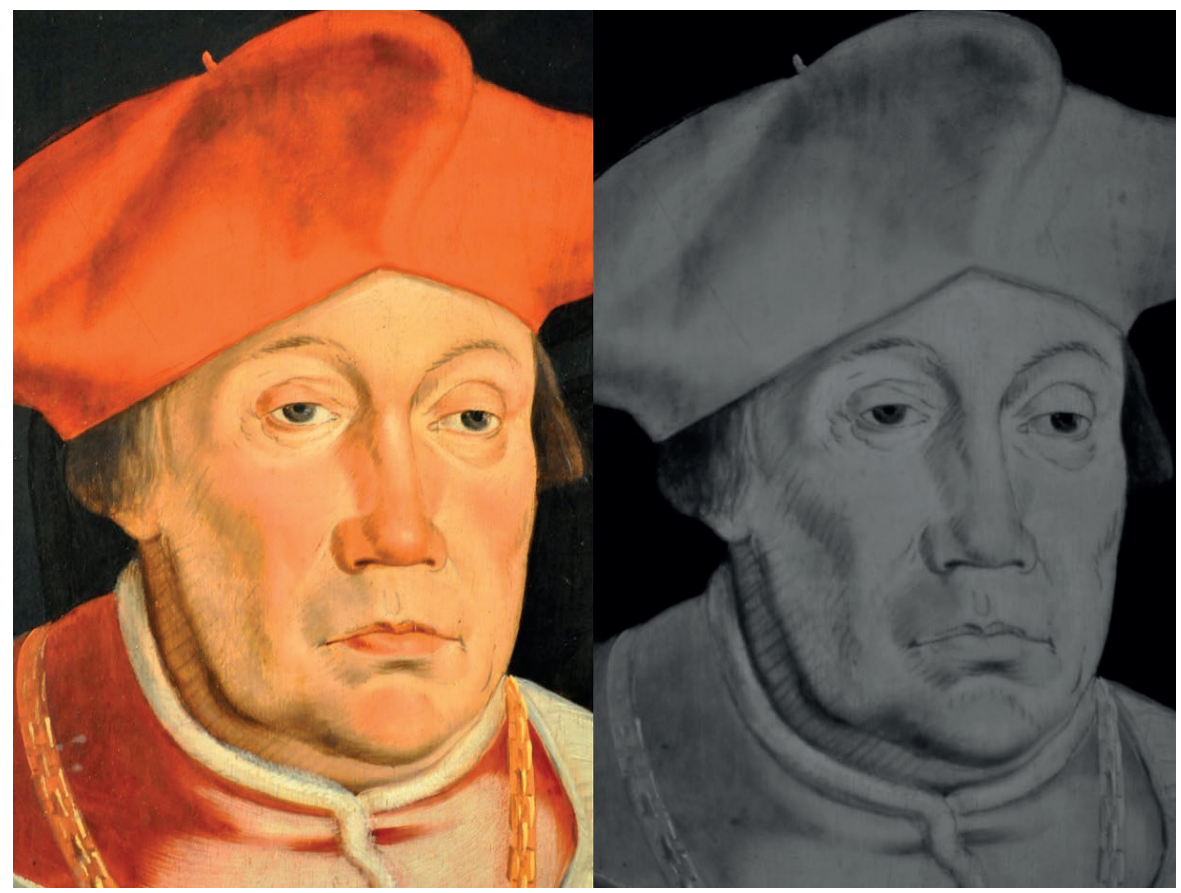

Fig. 6. Portrait of the Bishop Mauritius Ferber, Anton Möller, 1590. Fragment. Photography under the VIS and infrared reflectography IR. Parallel lines of the drawing are visible through the painting layer. Photo by Bożena Szmelter-Fausek 

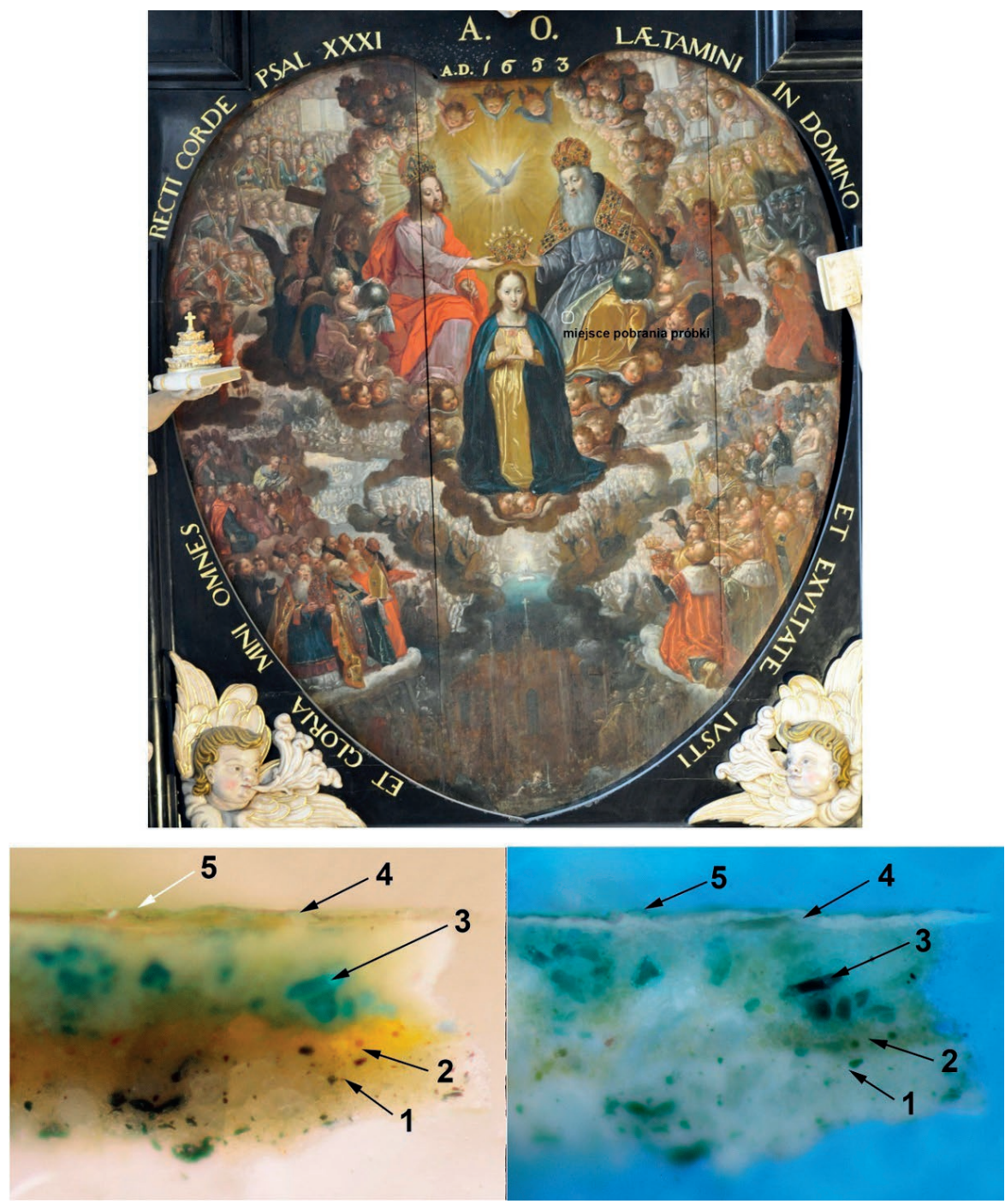

Fig. 7. Coronation of Mary, Hermann Han, after 1624, Holy Trinity Church (Cathedral) in Oliwa. Cross-section of a sample of green robe. Photography under the VIS and UV. Photo by Bożena Szmelter-Fausek and Zuzanna Rozłucka

1 - grey ground: lead white $2 \mathrm{PbCO}_{3} \times \mathrm{Pb}(\mathrm{OH})_{2}$, charcoal; 2 - yellow painting layer: lead-tin yellow type I $2 \mathrm{PbOxSnO}_{2}$, iron red; 3 - blue painting layer: natural azurite $2 \mathrm{CuCO}_{3} \times \mathrm{Cu}(\mathrm{OH})_{2}$, lead-tin yellow type I $2 \mathrm{PbOxSnO}_{2}$, lead white $2 \mathrm{PbCO}_{3} \times \mathrm{Pb}(\mathrm{OH})_{2}$; 4 - original varnish; 5 - secondary varnish 

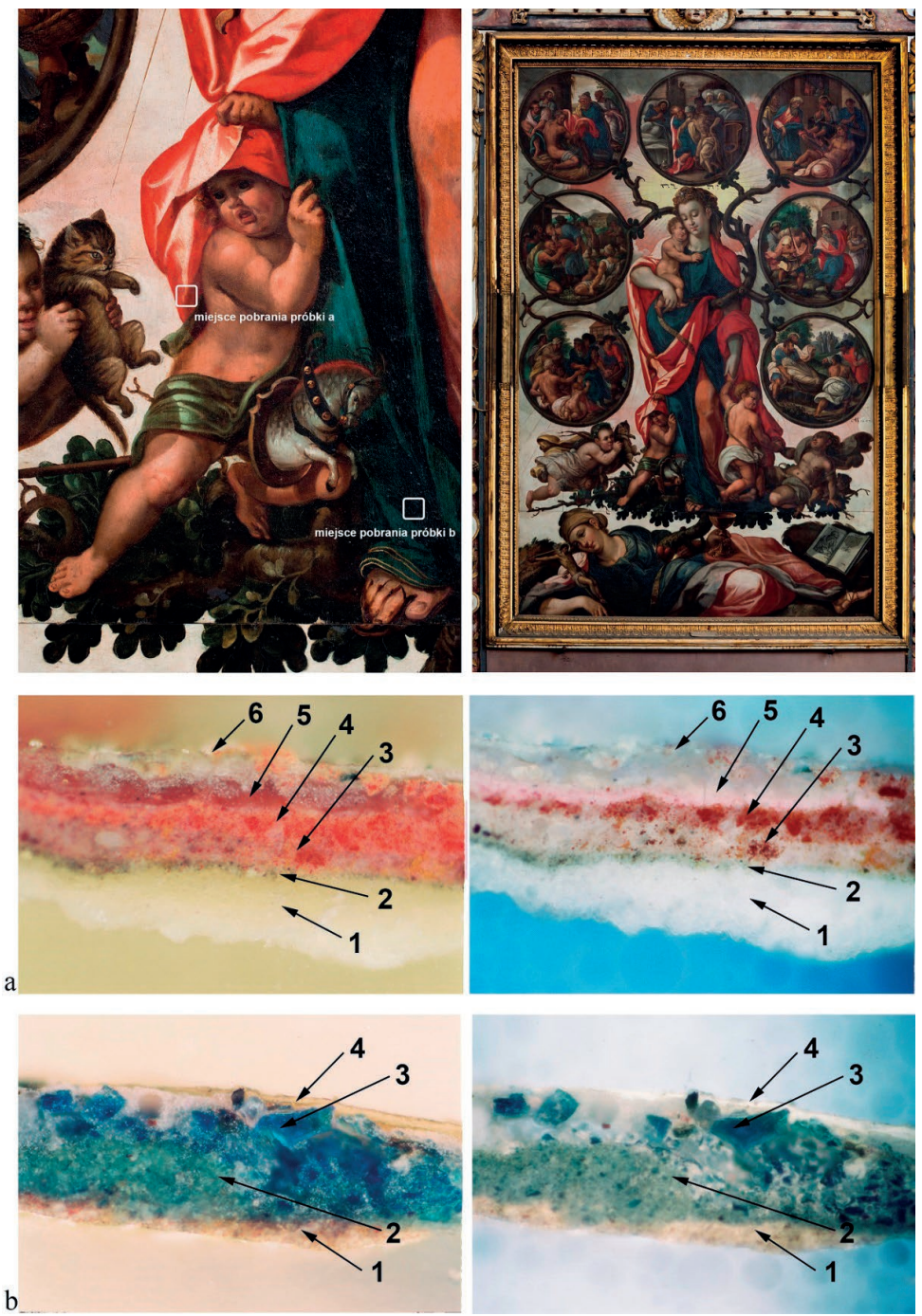

Fig. 8. Seven Acts of Charity, Anton Möller, 1607. Cross-section of a sample of red and blue robes. Photography under the VIS and UV. Photo by Andrzej Skowroński and Zuzanna Rozłucka

a) red robe: 1 - white ground: chalk $\mathrm{CaCO}_{3} ; 2$ - brown underpainting: organic black, iron red $\mathrm{Fe}_{2} \mathrm{O}_{3}$, lead white $2 \mathrm{PbCO}_{3} \times \mathrm{Pb}(\mathrm{OH})_{2} ; 3$ - red painting layer: organic red indicating carmine, vermilion $\mathrm{HgS}$, iron red $\mathrm{Fe}_{2} \mathrm{O}_{3}$, lead white $2 \mathrm{PbCO}_{3} \times \mathrm{Pb}(\mathrm{OH})_{2} ; 4$ - red painting layer: vermilion $\mathrm{HgS}$, iron red $\mathrm{Fe}_{2} \mathrm{O}_{3}$, organic red indicating carmine, lead white $2 \mathrm{PbCO}_{3}$ $\mathrm{x} \mathrm{Pb}(\mathrm{OH})_{2} ; 5$ - red lake: organic red indicating carmine; 6 - varnish

b) blue robe: 1 - brown underpainting: organic black, iron red $\mathrm{Fe}_{2} \mathrm{O}_{3}$, lead white $2 \mathrm{PbCO}_{3} \mathrm{x}$ $\mathrm{Pb}(\mathrm{OH})_{2} ; 2$ - blue painting layer: natural azurite $2 \mathrm{CuCO}_{3} \times \mathrm{Cu}(\mathrm{OH})_{2}$, lead white $2 \mathrm{PbCO}_{3} \mathrm{x}$ $\mathrm{Pb}(\mathrm{OH})_{2} ; 3$ - blue painting layer: natural azurite $2 \mathrm{CuCO}_{3} \times \mathrm{Cu}(\mathrm{OH})_{2}$, natural ultramarine $3 \mathrm{Na}_{2} \mathrm{O} \times 3 \mathrm{Al}_{2} \mathrm{O}_{3} \times 6 \mathrm{SiO}_{2} \times 2 \mathrm{Na}_{2} \mathrm{~S}$, lead white $2 \mathrm{PbCO}_{3} \times \mathrm{Pb}(\mathrm{OH})_{2}$, chalk $\mathrm{CaCO}_{3} ; 4$ - varnish 


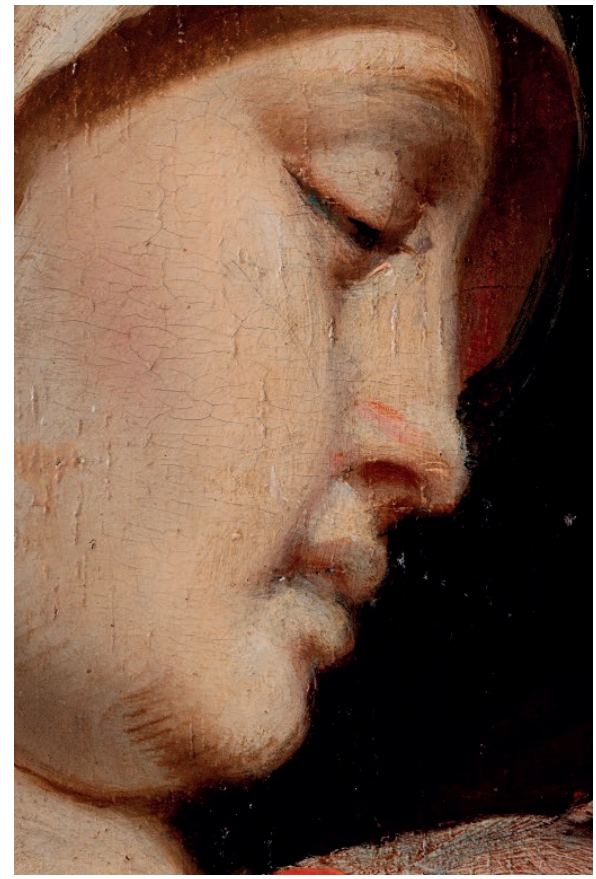

Fig. 9. Crucifixion, Anton Möller, 1609-1611. Fragment. Characteristic parallel brown lines of drawing emphasizing the shadows on the chin are visible. Photo by Andrzej Skowroński

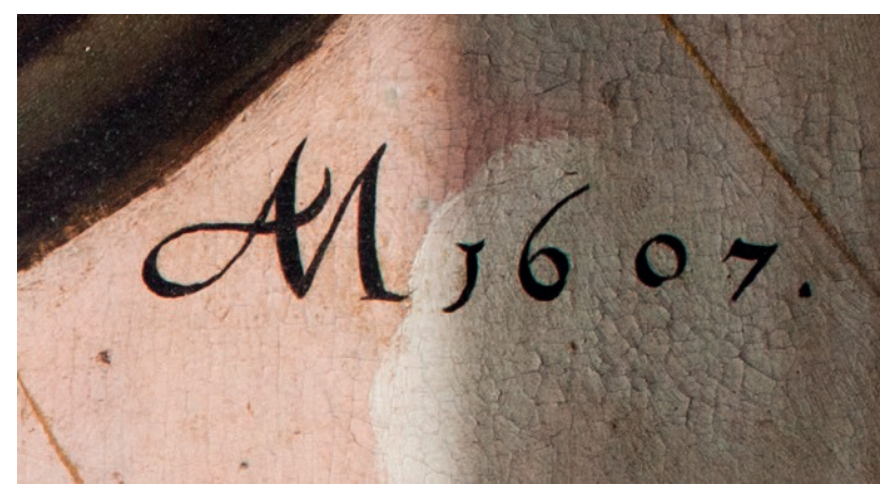

Fig. 10. Seven Acts of Charity, Anton Möller, 1607. Signature AM in ligature 1607 made by Anton Möller the artist. Photo by Andrzej Skowroński 
